\title{
- DISCURSO JUDICIAL SOBRE O TRÁFICO E USO DE DROGAS: uma análise das sentenças do Tribunal de Justiça do Rio de Janeiro
}

\author{
Felipe Francisco Peixoto Azeredo \& \\ José Roberto Franco Xavier?
}

\section{Palavras-Chave}

lei de drogas/análise de jurisprudência/ pesquisa empírica em direito/ diferenciação entre usuários e traficantes.

\section{SUMÁRIO}

1. Introdução. 2. Metodologia. 3. Um balanço das pesquisas sobre as inovações e a recepção da atual lei de drogas. 4. A aplicação da lei de drogas. 5. As justificativas encontradas nas sentenças do TJ-RJ. 5.1. Sentenças condenatórias. 5.1.1. Inferências probatórias: A) Descrição do Flagrante; B) Confissão; C) Materiais Apreendidos; D) Características do Acusado; E) Local da Prisão. 5.1.2. Fundamentos das inferências: Representações. 5.1.3. Controle de Prova: Credibilidade dos Meios e elementos de Provas. 5.2. Sentenças Absolutórias. 5.2.1 Inferências probatórias: A) Descrição da Prisão; B) Materiais Apreendidos; C) Características do Acusado; D) Local da prisão; E) Ministério Público pediu a absolvição. 5.2.2. Fundamentos das inferências: Representações. 5.2.3 Controle de Prova: Credibilidade dos Meios e elementos de Provas. 6. Conclusão. 7. Referências.

\section{Resumo}

A atual lei de drogas estipulou critérios para a diferenciação entre os crimes de uso e tráfico de drogas, estabelecendo diferentes modelos de resposta estatal para esses dois crimes. Esta pesquisa debruça-se sobre sentenças que versam sobre o crime de tráfico de drogas para entender como os juízes diferenciam os crimes de uso e tráfico. A partir da análise de uma amostra de todas decisões de primeira instância do Tribunal de Justiça do Estado do Rio de Janeiro do ano de 2015, pudemos estabelecer uma série de categorias pelas quais os magistrados justificam a sua decisão em matéria de tráfico de drogas. Trata-se aqui de uma pesquisa empírica de cunho qualitativo, que contou com a técnica de análise de documentos como base. A análise foi realizada lançando-se mão da teorização fundamentada nos dados (TFD) e os resultados apontam, em conformidade com a literatura da área, para a centralidade da prova testemunhal na distinção entre usuários e traficantes.

Felipe Francisco Peixoto Azeredo é aluno de graduação de Direito da Universidade Federal do Rio de Janeiro e pesquisador da FAPERJ. $<$ franciscofelipepa@gmail.com>. José Roberto Franco Xavier é professor do Departamento de Teoria do Direito e da do Programa de Pós-Graduação em Direito da Universidade Federal do Rio de Janeiro. <jfrxavier@gmail.com>. 


\title{
JUDICIAL ACCOUNTS OF DRUG TRAFFICKING AND DRUG USE: an analysis of the first instance decisions of the Court of the State of Rio de Janeiro
}

\author{
Felipe Francisco Peixoto Azeredo \& \\ José Roberto Franco Xavier
}

Key words

drug bill/ analysis of the legal decisions/ legal empirical research/differentiation between drug users and drug traffickers.

\section{SUMMARY}

1. Introduction. 2. Methodology. 3. An assessment of the research papers concerning the innovations and the acceptance of the current drug bill. 4. The enforcement of the drug bill. 5. The justifications found in the sentences from TJ-RJ. 5.1. Condemnatory judgments. 5.1.7. Probatory Inferences: A) Description of in flagrante delicto Arrests; B) Confession; C) Seized Materials; D) Characteristics of the Defendant; E) Site of Arrestment. 5.1.2. The Basis of Inferences: Representation. 5.1.3: Evidence Control: Credibility of the means and elements of proof. 5.2. Absolutory judgments. 5.2.1. Probatory Inferences: A) Description of in flagrante delicto Arrests; B) Seized Materials; C) Characteristics of the Defendant; D) Site of Arrestment; E) Prosecutor requesting acquittal. 5.2.2. The Basis of Inferences: Representation. 5.2.3: Evidence Control: Credibility of the means and elements of proof. 6 . Conclusion. 7. References.

\begin{abstract}
The current drug legislation established certain criteria to distinguish the crimes of drug use and trafficking, creating two different models of state response to these crimes. This research focuses on sentences related to drug trafficking crimes in order to understand how judges draw a distinction between drug users and drug traffickers. We have analyzed a sample of all the first instance sentences from the Court of the State of Rio de Janeiro in 2015 in order to establish a series of categories which allow judges to justify their decisions in drug trafficking cases. This research is an empirical qualitative legal research based on document analysis as the basic research technique. The analysis of the data was conducted through a grounded theory framing and the results point to the key role of the witnesses in the decision-making process of the judges.
\end{abstract}




\section{INTRODUÇÃO}

Em 2006, foi promulgada no Brasil uma nova lei de drogas (lei 11.343/06) que pretendeu implementar uma nova política de drogas para o Brasil. Como já estudado pela literatura nacional (Alvarez \& Campos, 2017; Boiteux et al., 2009; Campos, 2015; Pires \& Cauchie, 2011), havia naquele momento uma pretensão de se fazer uma distinção bastante clara entre usuário e traficante. Aos usuários, vistos como vítimas dos traficantes, seria implementado um modelo médico-normativo, no qual este deveria ser encaminhado para a assistência médica com o objetivo de tratar seu vício e ser conscientizado dos perigos deste. Pretendia-se afastá-los da prisão (Campos, 2015, p. 55), punindo-os somente com as chamadas penas alternativas, tais como advertência ou prestação de serviços à comunidade (art. 28, incisos I a III, Lei 11.343/06). Para os traficantes, representados pelos parlamentares como agentes corrompedores dos usuários, foi reservado outro modelo: o da intensificação da punição (Campos, 2015). Aumentou-se a pena mínima para o crime de tráfico de três para cinco anos, o que dificulta a possibilidade de cumprir a punição em regime aberto ou de ter a pena de prisão convertida em penas restritivas de direito. $^{2}$

Se no entanto a intenção do legislador de distinguir usuário de traficante era clara, os critérios para diferenciar esses dois tipos penais (art. 28, $\$ 2^{\circ}$, Lei 11.343/06) ${ }^{3}$ deixaram uma enorme margem de interpretação para os agentes do sistema de justiça cri-

\footnotetext{
O Código Penal brasileiro estabelece como requisito ao direito a estes benefícios uma condenação máxima de 4 anos de prisão (art. 33 $\$ 2^{\circ}$ e art.44, I, ambos do Código Penal).

3"Para determinar se a droga destinava-se a consumo pessoal, o juiz atenderá à natureza e à quantidade da substância apreendida, ao local e às condições em que se desenvolveu a ação, às circunstâncias sociais e pessoais, bem como à conduta e aos antecedentes do agente" (art. 28, §2, Lei 11.343/06).
}

minal (Boiteux et al., 2009, p. 37). No Rio de Janeiro, local em que a pesquisa foi realizada, há ainda uma condição especifica para a diferenciação, em razão do entendimento sumulado pelo Tribunal de Justiça do Estado (súmula n 70, TJRJ) de que processos cuja prova oral se limite aos testemunhos de autoridades policiais podem ensejar condenação. Pesquisas como a de Lemgruber e Fernandes (2015) apontam que nos processos judiciais sobre o crime de tráfico não é comum a existência de outras provas para além do testemunho dos agentes de segurança que prenderam o acusado. Tal dado aponta para a importância dos testemunhos desses agentes como meio de prova em um processo judicial portanto no processo de diferenciação especialmente quando há instrumentos institucionais que legitimem seu uso para esse fim.

A preocupação em pensar a distinção entre os tipos penais de tráfico e uso de drogas mostra-se ainda mais relevante quando se percebe que o crime de tráfico de drogas é o segundo com maior incidência entre os presos do país (Brasil, 2019, p. 69). A questão é ainda mais sensível quando se constata que, caso fossem adotados critérios de quantidades de outros países que descriminalizaram o uso, 60\% a $80 \%$ das apreensões feitas no Rio de Janeiro de 2006 até 2016, por exemplo, seriam registradas como uso (Instituto de Segurança Pública (ISP), 2016, p. 16).

É nesse cenário que a presente pesquisa se insere. Os autores estão interessados em saber como os juízes justificam em suas sentenças a comprovação da prática do crime de tráfico. Quais são as justificativas consideradas válidas para determinar a intenção de traficar e quais provas funda- 
mentam essas justificativas? ${ }^{4}$ Como podemos descrever e organizar esse conjunto argumentativo de forma a observar quais são os argumentos que têm prevalecido para a tomada de decisão?

Ao final da pesquisa, apresenta-se o mapeamento dos argumentos utilizados pelos magistrados no que chamamos de categorias de justificativas. Percebe-se que o principal elemento de prova usado pelos juízes para justificar a posse de drogas pelo acusado e a intenção de traficar são os depoimentos dos agentes de segurança, especialmente por serem majoritariamente as únicas testemunhas ouvidas. Entretanto, nota-se que outras justificativas, baseadas em outros elementos de prova, também fundamentam a comprovação da autoria de tráfico. Observou-se também que para além de justificativas para a condenação com base em elementos de provas, os magistrados, em alguns casos, também fundamentaram o raciocínio feito com base nesses elementos. Em geral, esses fundamentos remetem a representações estereotipadas do que seria o tráfico enquanto fenômeno social. Por último, destaca-se que os magistrados também buscam fundamentar os elementos e meios de prova usados como fonte para o raciocínio probatório apelando para justificativas baseadas em construções normativas, pragmáticas e idealistas.

\section{METODOLOGIA}

Para se chegar às conclusões pretendidas nesta pesquisa, lançamos mão de uma pesquisa empírica qualitativa baseada em análise de documentos. Mais especificamente, estabelecemos uma amostra aleatória

${ }^{4}$ Deve-se precisar o significado das expressões prova, elemento de prova e meio de prova. Uso o termo prova de maneira genérica, que rendo dar a entender tanto elemento quanto meio de prova. Chamo de elemento de prova a informação utilizada pelo juiz como fundamento da sua decisão, e.g., o conteúdo de um testemunho e meio de prova a fonte dessa informação, e.g., a testemunha.

de $10 \%$ de todos os processos envolvendo tráfico de drogas disponíveis no banco de dados do Tribunal de Justiça do Estado do Rio de Janeiro, disponibilizado à Diretoria de Estudos e Pesquisas de Acesso à Justiça da Defensoria Pública do Estado do Rio de Janeiro (DEPAJ/DPERJ), e analisamos em profundidade os argumentos contidos nas sentenças dos processos que compunham essa amostra.

Alguns esclarecimentos são importantes para que o leitor possa compreender as etapas da pesquisa. A fonte do material utilizado nesta pesquisa foi parte da base de dados fornecida pela DEPAJ/DPERJ, a mesma utilizada pela referida Diretoria de Pesquisas para elaborar o seu Relatório Final Pesquisa Sobre as Sentenças Judiciais por Tráfico De Drogas na Cidade e Região Metropolitana do Rio de Janeiro, lançado em 2018. Nessa base, estavam disponíveis o número de identificação de todos os processos distribuídos pelo TJRJ que versavam sobre o crime de tráfico de drogas (art. 33 da Lei de Drogas) no ano de 2015, distribuídos nas comarcas da região metropolitana do Rio de Janeiro. ${ }^{5}$

Desse total de processos - 2938, sorteamos 294 casos. Embora a pesquisa não tenha caráter quantitativo, trata-se de uma amostra de tamanho relevante para poder assegurar a possibilidade de generalização. Ainda que a generalização que se pretenda nesta pesquisa seja por saturação empírica ${ }^{6}$ da análise de documentos, estamos trabalhando

Havia também dados de 2014, mas o ano de 2015 era o mais completo na base. Não temos como estimar a diferença entre todas as decisões prolatadas nesse ano e as que compõem a base de dados, todavia essa base seguramente tem um acervo próximo à totalidade pois trata-se da mesma base utilizada pelo Tribunal para a sua informação. (Ver Haber, Carolina D. (Coord.). Relatório Final Pesquisa Sobre as Sentenças Judiciais por Tráfico De Drogas na Cidade e Região Metropolitana do Rio de Janeiro. Departamento de Pesquisa, Defensoria Pública Geral do Rio de Janeiro. 2018, p. 8)

${ }^{6}$ Ver Pires, Álvaro. Amostragem e pesquisa qualitativa. In. J. Poupart et al. A pesquisa qualitativa. Trad. Ana Cristina. Petrópolis, RJ. 2 ed. Vozes, 2010. p. 172. 
com uma amostra expressiva em termos quantitativos. Em termos qualitativos, não nos preocupamos na diversificação inicial da amostra (diversificação das comarcas, diversificação de perfis de magistrados, diversificação de perfis socioeconômico dos acusados, etc.), justamente por estar trabaIhando com uma amostra grande (294 casos) para padrões qualitativos.

Na tabela abaixo, pode-se observar a distribuição das sentenças analisadas entre condenatórias, absolutórias e não analisadas. Destaca-se que em todos os processos analisados os réus foram denunciados pelo artigo 33 da Lei de Drogas. Por isso, sentenças condenatórias e absolutórias são, respectivamente, as que os réus foram condenados ou absolvidos pelo crime do artigo 33. Já as sentenças não analisadas, são aquelas que não continham qualquer material interessante para análise, seja porque não tivemos acesso ao seu conteúdo por tramitarem em segredo de justiça, seja porque seus processos foram encerrados pela extinção de punibilidade do acusado em virtude de falecimento do réu ou prescrição.

\begin{tabular}{|c|c|c|}
\hline Tipo & Número & Porcentagem \\
\hline Condenatórias & 213 & $72 \%$ \\
\hline Absolutórias & 47 & $16 \%$ \\
\hline Não analisadas & 34 & $12 \%$ \\
\hline Total & 294 & $100 \%$ \\
\hline
\end{tabular}

Por se tratar de sentenças, ressalta-se que os resultados aqui apresentados não revelam quais aspectos os juízes realmente consideram ao julgar os casos. Como aponta Prates (2013, p. 111), nem todos os procedimentos utilizados pelos juízes para construir a sua decisão aparecem nos autos do processo.

Dessa forma, o que as sentenças nos reve- lam são quais justificativas os magistrados entendem necessário explicitar para que sua decisão seja considerada institucionalmente válida, diminuindo a chance de ser revisada pela instância superior. Eventualmente, essas justificativas podem corresponder aos critérios realmente utilizados pelo magistrado, porém também é possível que outros fatores valorados não sejam expostos na sentença, uma vez que eles poderiam fragilizar a validade da decisão.

Em razão da abordagem indutiva, optou-se por analisar as sentenças utilizando o método desenvolvido pela Grounded Theory, ou Teoria Fundamentada nos Dados (TFD). Esta metodologia de análise propõe formular noções teóricas a partir dos dados estudados na pesquisa, abrindo mão de elaborar hipóteses antes da ida a campo, no caso deste projeto, antes da análise dos documentos (Glaser \& Strauss, 2011, p. 22-23).

Desse modo, mediante um processo indutivo de categorização dos dados, buscamos a partir da análise empírica criar as nossas próprias categorias analíticas que explicassem o fenômeno observado.

Tal qual qualquer opção metodológica, a maneira escolhida para analisar os dados gera consequências. Por um lado, entendemos que há uma forte conexão entre os resultados mais gerais e sistematizados, as categorias, e os dados a partir dos quais elas foram construídas (Glaser \& Strauss, 229230). Por outro lado, há uma "diferença ontológica entre os resultados apresentados e os dados" (Cappi, 2017b, p.415). Dessa maneira, apesar de defendermos que há uma forte correlação entre eles, reconhecemos, como Cappi (2017a., p. 82-83), que o processo de sistematização resulta de escolhas do pesquisador, o que invariavelmente aca- 
ba por deixar materiais fora das categorias mais gerais.

O processo para a formulação das categorias de justificativas pode ser reconstruído em quatro etapas. (i) Inicialmente, recortamos os trechos das primeiras sentenças analisadas onde figuravam justificativas às decisões. (ii) Com o avanço da pesquisa, passamos a comparar os recortes e a reuni-los em conjuntos mais gerais baseados em unidade de sentido compartilhada, um fundamento similar. (iii) Formulamos as categorias de justificativas finais a partir do agrupamento de categorias iniciais. (iv) Dividimos as categorias de justificativas em três grupos de acordo com aquilo que elas buscavam justificar.

A tabela abaixo ilustra os passos de (i) a (iii). Observa-se, da esquerda para a direita, o trecho recortado da sentença que contém uma justificativa para a condenação, as primeiras categorias iniciais e a categoria final.

\section{Trecho}

"entendo que os depoimentos prestados pelos policiais militares foram coesos e descreveram de maneira uniforme a dinâmica dos fatos, afirmando que viram Alexssander se desfazer da bolsa na qual estavam os entorpecentes apreendidos" (Sentença do processo $\mathrm{n}^{\circ}$ 000630-12.2015.8.19.0039, p. 4).

"as provas da autoria e materialidade do crime são firmes e indiscutiveis [...] em razão de o acusado residir sozinho, porém, manter toda a droga em esconderijos diversos pela casa, pois que localizada pelos policiais em três lugares distintos e que não são de fácil acesso " (Sentença do processo $\mathrm{n}^{\circ}$ 0003507-90.2015.8.19.0081, p. 2).

\begin{tabular}{|l|l|}
\hline Categorias Iniciais & Categoria Final \\
\hline $\begin{array}{c}\text { Informações narradas nos } \\
\text { testemunhos }\end{array}$ \\
\hline $\begin{array}{c}\text { Drogas encontradas após } \\
\text { o acusado se desfazer dela }\end{array}$ \\
\hline $\begin{array}{c}\text { Informações narradas nos } \\
\text { testemunhos }\end{array}$ \\
\hline $\begin{array}{c}\text { Drogas encontradas na } \\
\text { casa do acusado }\end{array}$ \\
\hline $\begin{array}{c}\text { Forma de armazenamento } \\
\text { das drogas }\end{array}$ \\
\hline
\end{tabular}

Ao final, construímos 7 categorias de justificativas para condenar e 7 para absolver, sendo 6 dessas categorias comuns aos dois tipos de sentença.7 Dividimos as categorias finais em três grandes grupos (passo iv) com base naquilo que os magistrados buscavam justificar ao se utilizarem dessas categorias.

O primeiro grupo foi chamado de inferências probatórias. Inferência probatória é o raciocínio que conclui uma hipótese sobre um fato a partir de determinado elemento

\footnotetext{
É importante destacar que alguns trechos foram utilizados para a construção de mais de uma categoria. Por exemplo, se o juiz entende que não foi possível determinar a quantidade de drogas em posse do acusado com base na descrição do flagrante pelas testemunhas, entendemos que esse trecho se encaixa ao mesmo tempo em duas categorias: Descrição do Flagrante, pois há um argumento com base na descrição da prisão e Materiais Apreendidos porque há outro com base na quantidade de drogas apreendidas.
}

de prova (Herdy \& Matida, 2016, p. 213). Por isso, encontram-se nesse grupo as categorias que buscam justificar a autoria e a posse de drogas com base nos elementos de provas. O segundo grupo foi chamado de fundamentos da inferência probatória. Chama-se de fundamento ou garantia de uma inferência a "proposição, frequentemente implícita e de caráter geral, que enuncia um princípio, uma regra ou uma cadeia de raciocínio" que justifica o raciocínio feito na inferência probatória (Toulmin, 1958, p. 91, apud Herdy \& Matida, 2016, p. 216). ${ }^{8}$ Assim, nesse segundo grupo estão as justificativas ${ }^{8}$ Utilizamos as noções da epistemologia jurídica (Legal Epistemology) de inferência probatória e garantia ou fundamento da inferência somente como ferramentas que permitem melhor organizar a análise das justificativas. Não temos qualquer objetivo neste trabalho em nos engajar nas discussões feitas nesse campo. 
que buscam fundamentar a própria possibilidade das inferências probatórias. Já no terceiro grupo, controle de provas, encontram-se as justificativas que fundamentam a seleção das fontes da decisão, i.e., porque determinados meios e elementos de prova podem ser utilizados como fontes dos fundamentos da decisão e outros não.

Nas tabelas abaixo pode-se observar a divisão final das categorias de justificativas construídas ao longo da pesquisa.

\begin{tabular}{|c|c|c|c|c|c|c|}
\hline \multicolumn{7}{|c|}{ Justificativas para condenar } \\
\hline \multicolumn{5}{|c|}{ Inferências probatórias } & Fundamentos das & Controle de \\
\hline $\begin{array}{l}\text { Descrição do } \\
\text { Flagrante }\end{array}$ & Confissão & $\begin{array}{c}\text { Materiais } \\
\text { Apreendidos }\end{array}$ & $\begin{array}{c}\text { Características } \\
\text { do Réu }\end{array}$ & Local & Representações & $\begin{array}{l}\text { Credibilidade dos } \\
\text { Meios e } \\
\text { Elementos Provas }\end{array}$ \\
\hline
\end{tabular}

\begin{tabular}{|c|c|c|c|c|c|c|}
\hline \multicolumn{7}{|c|}{ Justificativas para absolver } \\
\hline \multicolumn{5}{|c|}{ Inferências probatórias } & Fundamentos das & Controle de \\
\hline $\begin{array}{c}\text { Descrição do } \\
\text { Flagrante }\end{array}$ & $\begin{array}{c}\text { Materiais } \\
\text { Apreendidos }\end{array}$ & $\begin{array}{c}\text { Características } \\
\text { do Réu }\end{array}$ & Local & $\begin{array}{c}\text { MP pediu } \\
\text { Absolvição }\end{array}$ & Representações & $\begin{array}{l}\text { Credibilidade dos } \\
\text { Meios e } \\
\text { Elementos Provas }\end{array}$ \\
\hline
\end{tabular}

3. UM BALANÇO DAS PESQUISAS SOBRE AS INOVAÇÕES E A RECEPÇÃO DA ATUAL LEI DE DROGAS

Como já mencionado, a diferenciação proposta pela lei 11.343/06 formulou diferentes modelos de resposta estatal para os crimes de uso e de tráfico e estabeleceu critérios para diferenciar esses crimes. Todavia, esses critérios foram criticados por não serem objetivos.

Pode-se afirmar que o $\S 2^{\circ}$ da Lei de Drogas estabeleceu critérios duplamente subjetivos. Primeiro, por não apresentar qualquer parâmetro objetivo de aplicação (Boiteux, 2011, p.39; Igarapé, 2015). Dessa forma, cabe ao agente (policial, delegado, promotor, juiz) definir que quantidade, natureza, local e condições correspondem à intenção de tráfico e quais à de uso. Atribui-se à subje- tividade dos agentes do sistema de justiça criminal um papel relevante na distinção (Boiteux, 2011). Segundo, em razão da existência de critérios relacionados às características do sujeito indiciado como autor que nada dizem respeito à ação tipificada como crime (Campos, 2015; Santoucy et al., 2010). São os critérios circunstâncias sociais e pessoais, conduta e antecedentes do agente. Assim, o que varia de um tipo penal para o outro não é propriamente a ação tipificada, mas simplesmente como o sistema de justiça criminal percebe determinados sujeitos (Boiteux et al., 2009, p. 37).

Como consequência da falta de objetividade, a literatura aponta a possível confusão entre as duas figuras legais (Pires \& Cauchie, 2011, p. 20; Couto et al. 2017, p. 2; Grilo et al. 2011, p. 9; Lemgruber \& Fernandes, 2015, p. 23). Devido à discricionariedade dos agen- 
tes do sistema criminal para classificar indivíduos presos com drogas, pode ocorrer a acusação e prisão de pessoas pelo crime de tráfico, mas que, em realidade, praticaram o crime de uso (Couto et al. 2017, p. 2).

O cenário se agrava quando pesquisas mostram que os próprios modelos de resposta estatal não foram perfeitamente implementados. Pires \& Cauchie (2011) apontam que por ser estranho ao sistema criminal, o qual normalmente estabelece a pena de prisão como única forma de sanção, o modelo de punição proposto para os usuários foi considerado uma "inovação" e recebido de maneira cética por teóricos e operadores do sistema de justiça. Há indícios de que os operadores dos juizados especiais, por exemplo, consideram que a escolha legislativa do fim da pena de prisão, na prática, descriminalizaria o uso. Eles entendem que sem a ameaça, ainda que indireta da pena de prisão, não seria possível dissuadir a prática do crime (Mendonça Filho, 2008, p. 7-8; Santoucy et al., 2010, p. 5).

Grilo et al. (2011) apontam que a percepção de uma descriminalização "na prática" pode ter levado a mudanças nas dinâmicas envolvendo as prisões de indivíduos encontrados com drogas pela polícia. Essa teria se tornado a principal responsável pela administração do crime de uso, devido ao desinteresse dos outros operadores do sistema de justiça que não veem sentido em penas alternativas.

Em entrevistas com operadores do sistema de justiça criminal de São Paulo, Jesus et al. (2011, p. 116) mostram que enquanto promotores e juízes entendem que a lei não diferenciou claramente os dois tipos penais, policiais militares não demonstram dificuldade em diferenciar usuários e traficantes, todavia, afirmam utilizar mais a sua própria experiência profissional do que os critérios elencados pela legislação.

É difícil negar a importância da polícia no processo de incriminação dos indivíduos encontrados com drogas. Desde a vigência da antiga lei de drogas, aponta-se a importância do papel da polícia e das negociações realizadas entre seus membros e indivíduos abordados por eles para a definição do tipo no qual esses indivíduos serão incriminados (Zaluar, 2004, p. 33 apud Boiteux, 2011, p.44).

Segundo Campos (2015), os legisladores discutiram a implementação dos critérios legais precisamente sob a alegação de tentar acabar com as negociações entre os indivíduos e os policiais. Porém, é interessante notar que os critérios parecem ter sido recebidos de maneira cética pelos operadores do sistema de justiça criminal.

\section{A APLICAÇÃO DA LEI DE DROGAS}

Mesmo que os modelos de resposta estatal ao crime de uso não tenham sido recebidos da maneira esperada e que os critérios de diferenciação permitam um grau significativo de discricionariedade aos agentes do sistema criminal para categorizar indivíduos presos com drogas, a estrutura do sistema de justiça demanda que a lei de drogas seja aplicada e que os juízes decidam se ficou provado que aqueles acusados de tráfico o praticaram ou não.

Quando se observam as pesquisas sobre a aplicação da nova legislação na fase judicial do processo, notadamente as que analisam o momento da decisão, quatro fenômenos identificados pela literatura chamam atenção: (i) a inexistência de um padrão na aplicação dos critérios e a presença de outros critérios que não os legais; (ii) julgamentos baseados em representações estereotipa- 
das dos acusados; (iii) a presença dos testemunhos de agentes de segurança pública como principal meio de prova e (iv) o caminho percorrido por esses processos dentro do sistema de justiça criminal.

(i) As pesquisas que analisam sentenças evidenciam como se reflete na aplicação da lei a falta de parâmetros dos critérios legais. Elas apontam para uma inexistência de um padrão na aplicação desses critérios. Por exemplo, ao analisar como os juízes justificam a condenação com base na quantidade de drogas apreendidas, as pesquisas verificam que as mais diferentes quantidades de drogas são utilizadas para justificar a condenação por tráfico. São encontradas com os acusados condenados quantidades que variam desde menos de dez gramas a mais de $10 \mathrm{~kg}$. Além disso, verifica-se que apreensões de quantidades semelhantes são utilizadas como justificativas tanto para condenar, quanto para absolver por tráfico (Alvarez \& Campos, 2017, p. 18; Boiteux, 2011, p. 58; Haber et al., 2018, p. 50; Jesus et al., 2011, p. 52; Lemgruber \& Fernandes 2015, p. 12).

É interessante destacar também os dados de Haber et al. (2018, p. 54-55), que mostram que os juízes do TJ-RJ raramente aplicam os critérios "circunstâncias sociais e pessoais do agente". Aponta-se também a existência de critérios estranhos aos do artigo 28 , como a variedade e forma de acondicionamento da droga, que muitas vezes são utilizados para justificar a autoria do tráfico (Haber et al., 2018, p. 80; Lemgruber \& Fernandes, 2015).

(ii) A análise da aplicação do critério local e da quantificação da pena dos condenados, revela que os juízes se justificam com base em representações estereotipadas da figura social do traficante aplicadas ao indivíduo julgado. Por exemplo, se o local da prisão do

réu for considerado pelo juiz como dominado por facções criminosas, os acusados tendem a ser condenados por associação ao tráfico, pois, segundo o estereótipo, não seria possível portar drogas nessas áreas sem pertencer ao tráfico (Haber et al., 2018). Já com relação à aplicação das penas, os juízes tendem a justificar penas mais altas para os acusados, apoiando-se na periculosidade associada à figura do traficante e às facções criminosas (Haber et al., 2018; Lemgruber \& Fernandes, 2015).

(iii) Outro dado que chama a atenção é a relevância da prova testemunhal. A literatura mostra que os testemunhos dos policiais que realizaram a prisão em flagrante são praticamente o único meio de prova nesses casos, além do exame pericial que constata a natureza e quantidade da substância apreendida.

Boiteux et al. (2009, p. 107), em uma das primeiras pesquisas em sentenças por tráfico de drogas após a promulgação da legislação atual, já descreviam esse fenômeno. Ao analisar sentenças dos tribunais do Distrito Federal e Rio de Janeiro proferidas entre 2006 e 2008, as autoras afirmam que na maioria dos casos as únicas testemunhas arroladas são os próprios policiais responsáveis pela prisão do réu. Haber et al. (2018, p. 35) mostram que no Rio de Janeiro, entre 2014 e 2016, em 62\% das sentenças analisadas o depoimento desses agentes foi a única prova testemunhal produzida e que, em 53\% dos casos, elas pareciam principalmente baseada nos depoimentos dos policiais. ${ }^{9}$

(iv) O cenário se mostra ainda mais problemático, porém ganha sentido, observando as condições das prisões desses acusados

Resultados semelhantes foram descritos pelas pesquisas de CarvaIho e Weigert (2018, p. 50); Jesus et. al. (2011) e Lemgruber e Fernandes (2015).

O DISCURSO JUDICIAL SOBRE O TRÁFICO E USO DE 
e o caminho percorrido por esses processos ao longo do modelo brasileiro de construção da verdade jurídica. A literatura mostra que, em geral, os processos são iniciados por prisões em flagrante e chegam à fase judicial sem maiores investigações durante o inquérito policial (Boiteux, et al. 2009; Couto et al. 2017; Haber et al., 2018; Jesus, 2015; Lemgruber \& Fernandes, 2015).

Além disso, Couto et. al. (2017, p. 418-419) mostram a velocidade com que esses processos são julgados. Estudando a vara especializada em crimes de tráfico do TJ de Belo Horizonte, os autores apontam que os crimes de tráfico são julgados em média 18 vezes mais rápidos que crimes de homicídio, durando aproximadamente um mês o período entre a distribuição e julgamento. Tal dado, segundo o autor, pode ser explicado pela homogeneidade dos casos apresentados à justiça e pela falta de questionamento à palavra do policial (p. 423). Couto et al. (2017, p. 416-417) e Lemgruber e Fernandes (2015, p. 13-14) apontam também para a baixa porcentagem de inquéritos que foram encerrados sem o oferecimento de denúncia.

Esse fenômeno, no entanto, é comum no sistema de justiça brasileiro: casos iniciados por prisões em flagrante geralmente não levam a grandes investigações policiais e são tratados de maneira diferenciada, passando rapidamente à fase judicial (Azevedo \& Vasconcelos, 2011; Costa \& Júnior, 2016; Misse, 2010; Vargas, 2012). Nesse sentido, as entrevistas elaboradas por Jesus et al. (2011, p. 6364) com agentes do sistema criminal são interessantes por mostrarem que eles próprios parecem compreender o flagrante como um "caso pronto", sendo possível dispensar maiores investigações.

Contudo, por serem casos iniciados por fla- grantes que em sua maioria ocorrem em via pública (Haber et al., 2018; Jesus, 2015; Jesus et al., 2011; Lemgruber \& Fernandes, 2015), estranha-se que não haja nem mesmo o pedido para a produção de outros tipos de prova (Lemgruber \& Fernandes, 2015, p. 17), como solicitar o acesso ao vídeo de câmeras de vigilância. A pesquisa realizada por Jesus et al. (2011, p. 55) indica que o momento do julgamento parece ser uma mera repetição do que foi colhido na fase de inquérito policial. A literatura também aponta para a existência de modelo de sentenças "cuja argumentação para condenação (79,97\% dos casos) ou absolvição (20,03\% dos casos) costuma vir previamente estruturada e pronta para se encaixar à realidade fática" (Haber et al. 2018, p. 59).

Outro fator encontrado é a precariedade da defesa da maioria dos acusados. Lemgruber e Fernandes (2015, p. 16) identificam modelos de defesa apresentados pela própria defensoria pública, o que pode reforçar a imagem de uma linha de produção da justiça, prejudicando a defesa do réu, bem como uma análise mais profunda do caso. As próprias autoras ressaltam a inexistência de argumentos convincentes e falta de provas que sustentem as afirmações nas teses defensivas. Jesus et al. (2011, p. 83-84) observam um fenômeno parecido nas audiências de instrução e julgamento: raramente as testemunhas de acusação são questionadas ou levanta-se a questão de que as provas apresentadas são frágeis. Na verdade, os autores apontam que as audiências tinham curta duração e sem muitas manifestações de defesa e acusação. Sua percepção foi a de que "as audiências se apresentavam mais como uma formalidade jurídica, do que [...] uma oportunidade para as partes se manifestarem e produzirem provas" (Jesus 
et al. 2011, p. 84-85).

Os pontos levantados são ainda mais preocupantes quando se considera que as pesquisas apontam que na maioria dos casos analisados, o resultado do julgamento é a condenação do acusado (Haber et al., 2018, p. 25, Jesus et al., 2011, p. 82; Lemgruber \& Fernandes,2015, p. 5-6).

\section{AS JUSTIFICATIVAS ENCONTRADAS NAS SENTENÇAS DO TJ-RJ}

Os resultados encontrados na pesquisa que deu origem a este artigo se assemelham aos problemas já apontados pela literatura e possibilitam que se jogue uma nova luz sobre eles. Inicialmente, apresentaremos as justificativas encontradas nas sentenças condenatórias e, a seguir, as encontradas nas sentenças absolutórias. Destaca-se que, como a base de dados utilizada para esse trabalho foi em parte a mesma usada por Haber et al. (2018), utilizaremos, no que for possível, os dados desta pesquisa em comparação e em suporte aos nossos.

\section{- Sentenças Condenatórias:}

\subsubsection{Inferências probatórias: ${ }^{10}$}

\section{A) Descrição do Flagrante:}

Encontramos nas sentenças analisadas diversas justificativas para a condenação do acusado cujo fundamento eram descrições do momento da prisão em flagrante dos acusados. Trata-se de argumentos que fazem referência ao conteúdo de testemunhos de pessoas que presenciaram a prática do crime de tráfico ou a prisão do acusado e referências ao conteúdo de documentos, como o auto de prisão em flagrante, que registram a prisão do réu.

As categorias apresentadas nesse primeiro grupo encontram paralelos nos resultados dos trabalhos de Campos (2015); Carvalho e Weigert (2018); Jesus (2015) Lemgruber e Fernandes (2015).
De uma maneira geral, as referências se dirigem a descrições explícitas da venda de drogas pelo acusado, a descrições de onde e como as drogas foram encontradas ou a descrições do contexto da prisão (se houve fuga, conflito, porque o acusado foi abordado).

Por exemplo, na sentença do processo de $\mathrm{n}^{\circ}$ 0014869-12.2015.8.19.0042, o juiz afirma que o acusado traficava, justificando-se no relato dos policiais que o avistaram vendendo drogas:

No que se refere à autoria, esta também restou plenamente demonstrada na espécie. (...) Constata-se que a testemunha reconheceu o acusado e, em seus depoimentos, tanto em juízo quanto em sede policial, relatou a dinâmica dos fatos". (Posteriormente, citando indiretamente o testemunho:) "A testemunha de acusação Carlos Renato dos Santos Dália, PMERJ (...). Relatou que a viatura policial ficou cerca de quinze minutos atrás de uma laje no local, tendo ouvido a conversa dos envolvidos por rádio transmissor que estavam em cima da laje. Declarou que em um dado momento avistou o réu com uma sacola na mão servindo uma outra pessoa" (p. 3; itálico dos autores).

Entretanto, também reunimos nessa categoria trechos de sentenças, como as do processo $n^{\circ} 0035062-60.2015 .8 .19 .0038$ e do $n^{\circ}$ 0004323-92.2015.8.19.0042, nas quais o juiz faz uma simples menção ao testemunho, afirmando que ele é um dos meios de prova que comprovam a prática de tráfico, sem citar direta ou indiretamente o trecho que sustentaria essa afirmação.

É interessante notar que, para além da autoria, as justificativas baseadas nas descrições do flagrante também são usadas para justificar o argumento de 
que o acusado era o possuidor das drogas apreendidas. Por exemplo, no processo $n^{\circ}$ 0019426-68.2015.8.19.0001, o juiz afirma:

Isto porque as testemunhas [policiais] que foram ouvidas durante a colheita da prova oral, em depoimentos uníssonos, não hesitaram em apontar o acusado como sendo a pessoa que trazia consigo as drogas e o rádio transmissor apreendido (p. 1).

Deve-se destacar que não só depoimentos de agentes de segurança serviram como meios de prova para as justificativas presentes nessa categoria. No processo $n^{\circ}$ 0044985-64.2015.8.19.0021, o juiz se utiliza tanto do depoimento dos policiais que descrevem terem observado o réu vendendo drogas e o contexto da sua prisão, quanto do depoimento de uma testemunha que afirma já ter comprado drogas do acusado.

Entretanto, o uso de outras testemunhas como fontes para o argumento baseado na descrição da prisão não afasta a conclusão de que o depoimento de policiais é central para a elaboração das justificativas nessa categoria. Isso porque os agentes de segurança pública que realizaram a prisão dos acusados figuraram como testemunha em todos os casos analisados nesta pesquisa e foram as únicas testemunhas em aproximadamente $64 \%$ dos processos."

Em qualquer processo, é esperado que o juiz dependa de terceiros para a reconstituição dos fatos que não presenciou. A questão a ressaltar nos processos da lei de drogas não é o uso de testemunhas, mas o estranhamento de ter quase que invariavelmente apenas testemunhas policiais como fontes exclusivas de condenação com rela-

\footnotetext{
Tal dado se aproxima da porcentagem encontrada por Haber et al. (2018, p. 53): em 62,33\% dos processos analisados por eles somente os policiais eram testemunhas.
}

ção a eventos que se deram no mais das vezes em via pública (Haber et al.,2018, Jesus et al., 2011, p. 38-39; Lemgruber \& Fernandes, 2015, p. 22). Na falta de outros elementos de prova, os operadores do sistema de justiça criminal costumam decidir com base nas circunstâncias do crime descritas pelos policiais que efetuaram as prisões (Carlos, 2015, p. 7).

\section{B) Confissão}

Nesta categoria, foram associadas justificativas cujo fundamento era a confissão do réu. Identificaram-se quatro modos diferentes, por meio dos quais o magistrado se utiliza de declarações do acusado como justificativa para condená-lo.

Uma das formas é por confissões feitas fora do julgamento. Os magistrados consideram informações trazidas pelos agentes de segurança de que o acusado teria confessado no momento da prisão que traficava ou na delegacia, registrada no inquérito ou auto de flagrante. Portanto, nesses casos não há uma confissão em juízo, mas ela é trazida por terceiros. ${ }^{12}$ Como no processo de $n^{\circ}$ 0000630-12.2015.8.19.0039, no qual o juiz afirma que ficou comprovada a autoria, dentre outros motivos, porque:

Os milicianos ainda declararam de forma unânime e harmônica que Alexassander teria afirmado quando de sua prisão que estaria no local para venda de entorpecentes, pois no município de Seropédica onde residia estaria difícil o comércio de drogas em razão da concorrência com outros traficantes (p. 4).

Outra maneira foi implicar, por meio do depoimento do réu, que este confessou o crime, ainda que não o tenha feito direta-

12 Jesus (2015, p. 228-229) também aponta que confissões informadas por policiais foram usadas como justificativas de condenações. 
mente. São casos em que a conduta narrada pelo réu em seu depoimento foi considerada uma confissão do crime de tráfico porque o magistrado entende que ela corresponde à conduta típica de tráfico descrita no art. 33 da Lei de Drogas. Na sentença do processo $n^{\circ}$ 0416905-85.2015.8.19.0001, o réu afirma que era usuário, mas às vezes revendia as drogas para seus amigos, mas sem admitir que traficava. Posteriormente, o juiz considera que como vender é uma das condutas típicas do artigo 33 da Lei de Drogas, ele considera que o réu confessou a prática do crime de tráfico e deve ser condenado. Em outros, como no processo de $n^{\circ}$ 0000875-20.2015.8.19.0040, o réu confessa um crime diferente, no caso, associação ao tráfico (art. 35 da Lei de Drogas), mas o magistrado entende que ele também descreve a prática de tráfico.

Houve ainda sentenças nas quais o depoimento do réu é a justificativa para comprovar a posse de drogas, sendo a intenção de tráfico indicado por outros elementos. Nesses casos, o juiz seleciona no depoimento do acusado o que ele considera como verdadeiro e o que ele considera como falso, pois o réu assume a propriedade ou posse de drogas, mas indica outra finalidade para elas, como uso. Na sentença do processo $n^{\circ}$ 0009270-10.2015.8.19.0037, o magistrado cita o depoimento do acusado, afirmando que este reconheceu a propriedade das drogas argumentando ser usuário, mas que no seu entender há "nos autos indícios de que a droga transportada pelo réu não serviria ao único e exclusivo deleite do réu" (p. 3).

O quarto modo encontrado foi justificar a condenação com base na confissão expressa do crime de tráfico em juízo. É interessante notar que, mesmo nesses casos, o magistrado apresenta outros argumentos

além da confissão. Na sentença do processo $n^{\circ}$ 0010283-28.2015.8.19.0204, o juiz justifica a condenação com base na confissão e também na descrição da prisão feita pelas testemunhas e nos materiais apreendidos.

Percebe-se que, semelhante à categoria anterior, a palavra do acusado, dita por ele ou por terceiros, é utilizada pelos magistrados para comprovar tanto a posse das drogas, quanto a autoria do crime de tráfico por demonstrar sua intenção de praticar o crime ou admitir ter praticado. ${ }^{13}$

\section{C) Materiais Apreendidos}

Esta categoria contém as justificativas baseadas nos materiais apreendidos, que podem ser divididas em quatro tipos. O primeiro trata da forma de acondicionamento da droga. São argumentos em que o juiz efetivamente valora a forma de embalagem da droga como indício de autoria do crime de tráfico, i.e., o acondicionamento e o modo de distribuição em diversos e determinados tipos de embalagens. Esse tipo de justificativa é encontrada tanto na forma de uma simples afirmação de que o acondicionamento da droga é um indício de autoria, como no processo $n^{\circ} 0047394-$ 13.2015.8.19.0021, quanto na forma de um argumento cujo fundamento é a distribuição da droga em diversas embalagens "prontas para venda" ou por suas embalagens conterem inscrições de facções criminosas, como na sentença do processo $n^{\circ} 0010466$ 93.2015.8.19.0011.

O segundo tipo fundamenta-se nas propriedades das drogas apreendidas: o tipo de droga, sua quantidade e variedade. Em relação ao tipo de droga, encontramos simples menções à sua "natureza" como ele-

${ }^{3}$ Haber et al. (2018, p. 37) mostram que a confissão expressa não é tão comum. No relatório dos autores, ela aparece somente em 4,75\% do total de casos analisados. 
mento que prova a intenção de tráfico. ${ }^{14}$ Já com relação à variedade encontramos referências à diversidade de tipos de drogas apreendidas. Assim, no processo n ${ }^{\circ} 0021143$ 88.2015.8.19.0204 (p. 2), associada à quantidade, a "variedade de drogas (maconha e cocaína) denota perfeitamente a sua [das drogas apreendidas] destinação comercial".

Quanto à quantidade de drogas apreendidas, observamos justificativas que utilizam tanto de simples menções à quantidade, sem maiores explicações, como também argumentos que defendem que como a quantidade apreendida é muito elevada para o uso, logo, a contrario sensu, elas se destinavam ao tráfico. Por exemplo, no processo $\mathrm{n}^{\circ}$ 0012491-82.2015.8.19.0204, o juiz afirma que: "[...] a droga devidamente acondicionada em quantidade e variedade não compatível para uma remota hipótese de consumo próprio, não deixam dúvidas sobre a veracidade dos fatos narrados na denúncia" (p.5). No mesmo sentido, os juízes argumentam que a quantidade de droga apreendida teria um grande valor de mercado, não sendo comum que um usuário fosse visto ou possuísse meios para comprá-la, como no processo nº 0003947-42.2015.8.19.0031.

Destaca-se também que observamos justificativas baseadas na pouca quantidade de drogas. Dentre esses casos, o processo de $n^{\circ}$ 0038833-06.2015.8.19.0213 é interessante porque o juiz afirma que a presença da polícia no local fez com que os traficantes passassem a circular com pouca quantidade de drogas. A justificativa para a autoria, então, é a pequena quantidade: “(...) após a instalação de posto fixo da Polícia Militar no

${ }^{4}$ Como, por exemplo, no processo n 0025713-78.2015.8.19.0023. Men ções mais detalhadas podem ser encontradas no trecho da sentença correspondente ao cálculo da pena, já que a quantidade aparece como justificativa para elevá-la. Todavia, como estávamos preocupados somente com a motivação da condenação não mapeamos esses trechos. chamado "container" da Chatuba, o tráfico assumiu característica mais "itinerante": feito em pequenas quantidades e de modo a dispersar rapidamente a "boca", no caso de aproximação da PM" (p. 2).

O terceiro tipo de justificativa fundamenta-se na apreensão de outros materiais além das drogas, como, por exemplo, cadernos com anotações de venda; materiais que seriam de preparo de drogas para venda; armas de fogo; rádios transmissores e dinheiro. ${ }^{15}$ As justificativas baseadas no dinheiro apreendido são um caso interessante de se destacar pela falta de parâmetro. Ao mesmo tempo em que encontramos sentenças, como a do processo $n^{\circ}$ 0002876-94.2015.8.19.0066, em que a divisão da pouca quantia (assim definida pelo juiz) apreendida em pequenas notas é usada como indício de comércio; no processo nº002923-49.2015.8.19.0040 é o alto valor ( $R \$ 2.500$ ) encontrado com o acusado de maneira injustificada, segundo o juiz, que indica o comércio.

Assim, as justificativas agrupadas nesta categoria mostram como os objetos apreendidos são utilizados pelos juízes para diferenciar tráfico e uso. Pode-se supor, portanto, que há um entendimento de que a partir dos objetos é possível depreender a intenção do acusado. Entretanto, não parece claro em quais circunstâncias esses objetos apontam para intenção de tráfico, já que se percebe uma falta de parâmetro no seu emprego enquanto justificativa. ${ }^{16}$

Haber et al. (2018, p. 49) apontam que a natureza e a quantidade das drogas foram encontradas, respectivamente, em 27,77\% e $82,49 \%$ das sentenças analisadas. A quan-

${ }^{5}$ Para anotações e materiais de endolação ver, por exemplo, a sentença do processo nº000341-98.2015.8.19.0065. Para um exemplo do uso de armas e radinhos ver o processo $n^{\circ}$ 0048836-60.2015.8.19.0038.

${ }^{16}$ Alvarez e Campos (2018, p. 62); Boiteux (2009); Haber et al. (2018, p. $62)$; Lemgruber e Fernandes (2015, p. 12) trazem dados semelhantes. 
tidade corresponde, assim, ao segundo argumento mais frequente encontrado pelos autores.

A sentença do processo $\mathrm{n}^{\circ}$ 004441104.2015.8.19.0001 é um bom exemplo de como os tipos de justificativas mencionadas nesta categoria são utilizadas em:

Com relação à finalidade do entorpecente, esta também se comprovou. Com efeito, a natureza entorpecente do material apreendido foi atestada com o laudo pericial de fl. 116, onde foi constatada a quantidade de $53 \mathrm{~g}$ de maconha, distribuídos em 32 embalagens plásticas com a inscrição "Hidropônica 5 PU CVRL" e 30 g de cocaína, acondicionados em 100 pequenos frascos plásticos do tipo eppendorf, com os dizeres "Maradona 5 PU CV". Assim, considerando as circunstâncias da prisão, os depoimentos dos policiais, somada a quantidade e forma de acondicionamento da droga, inquestionável a finalidade de mercancia do entorpecente (p. 3, grifo nosso)

\section{D)Características do Acusado}

Ao todo, observamos três tipos de fundamento para as justificativas que se estruturavam em torno de referências às características do acusado: o passado, reputação e capacidade mental e econômica do acusado. Com relação ao passado e reputação do réu, encontramos argumentos cujo fundamento era o seu "passado criminoso", descoberto a partir da folha de antecedentes de acusados ou de outras informações sobre o comportamento e vida do réu obtidas por meio de testemunhos. ${ }^{17}$ Os agentes que realizaram a prisão do acusado relatam em seu depoimento saber que o réu já teria pratica-

Para os antecedentes, ver, por exemplo, o processo de nº00042975.2015.8.19.0053. do outros crimes na região e estaria envolvido com grupos de tráfico, ou que ele já foi alvo de denúncias anônimas de moradores da região que o acusam de vender drogas. Por exemplo, no processo de $\mathrm{n}^{\circ} 0020204-$ 08.2015.8.19.0011 (p. 5), o magistrado afirma que "como consta de ambos os depoimentos [de policiais e outra testemunha de acusação], o acusado já era conhecido dos policiais, como gerente do tráfico de drogas na Comunidade do Cemitério".

Em relação à capacidade mental do acusado, estes argumentos são utilizados pelo juiz para rebater alegações da defesa que afirmam que na verdade o réu é um usuário de drogas e não traficante. Por um lado, juiz descarta a possibilidade do réu ser somente um usuário, afirmando, por exemplo, que suas ações não se coadunam com a de quem possuísse droga somente para uso. Esse é o argumento encontrado no processo nº 0017481-19.2015.8.19.0204, no qual o réu foi preso tentando entrar com drogas na cadeia e o juiz entende que usuários não adentrariam em penitenciárias com drogas. Por outro, o magistrado afirma que a condição de usuário não impede que o réu pratique o crime de tráfico e seja perfeitamente capaz de compreender suas ações, como no processo de $n^{\circ}$ 0013922-55.2015.8.19.0042.

Quanto à condição econômica do acusado, os juízes argumentam que a não comprovação de renda lícita ou a baixa renda comprovada são indícios de tráfico. Isso porque seu baixo salário não possibilitaria ao réu comprar a quantidade de droga apreendida, como no processo $n^{\circ} 0000153$ 54.2015.8.19.0082, ou aponta que o tráfico seria sua principal fonte de renda, por exemplo, o processo nº002359-15.2015.8.19.0026.

Dessa maneira, as justificativas organizadas 
nesta categoria mostram que um dos argumentos para fundamentar uma condenação por tráfico baseia-se em características subjetivas do réu que diretamente não trazem informações concretas sobre a prática do crime de tráfico. Além disso, percebe-se o quanto esses argumentos se baseiam em estereótipos, como o da carreira criminosa.

Com relação à frequência dessa categoria, ela corresponde a três categorias diferentes elaboradas por Haber et al. (2018, p. 56-57): circunstâncias sociais, circunstâncias pessoais do acusado e antecedentes. Os autores apontam que não é tão comum encontrar como justificativa para a condenação argumentos baseados em características do acusado. Estes foram encontrados em somente $8,84 \%$ das sentenças. Todavia, os antecedentes foram encontrados em $64,67 \%$ das sentenças. ${ }^{18,19}$

\section{E) Local da Prisão}

Outra forma de justificar a condenação foi fundamentando-a no local da prisão. Os juízes argumentam que o local da prisão, por ser um ponto conhecido de tráfico de drogas, como uma boca de fumo, permite inferir que as drogas se destinavam à venda. ${ }^{20}$

Observa-se que os juízes tanto não apresen-

${ }^{18}$ Há, entretanto, uma diferença na contabilização dos antecedentes entre a minha pesquisa e a de Haber et al. (2018). Os autores desta pesquisa contabilizaram os antecedentes quando eles apareciam em qualquer parte da sentenç, não somente na motivação da decisão. Dessa maneira, é possível que essa porcentagem não represente a real frequência do uso de antecedentes como justificativas para a condenação, já que eles também são utilizados para o cálculo da pena e, em alguns casos, estabelecimento do regime em que a condenação será cumprida.

9 Apesar da pesquisa de Haber et al. (2018) mostrar que critérios so ciopessoais parecem ser poucos utilizados como justificativas formais para a condenação, não se deve esquecer que eles podem influencia no processo de outras maneiras. A pesquisa de Jesus et al. (2011, p. 114) aponta, por exemplo, para um melhor tratamento entre aqueles considerados com maior poder aquisitivo, seja porque juízes entrevistados consideraram ser possível que estes carreguem uma maior quantidade de droga para consumo próprio, pois possuem condição financeira para comprá-la; seja porque, por serem defendidos por advogados particulares, o processo é tratado com mais atenção do que os assistidos pela defensoria pública, tradicionalmente mais pobres.

${ }^{20}$ Haber (2018); Jesus (2015); Lemgruber e Fernandes (2015) também encontraram dados semelhantes. tam a fonte da informação de que o local é conhecido pela prática de tráfico, como no processo de $n^{\circ}$ 0001733-78.2015.8.19.0031, quanto há sentenças nas quais eles explicitam sua fonte, indicando o testemunho dos agentes responsáveis pela prisão, que afirmaram que o local da prisão ponto de tráfico de drogas em seu depoimento. Como no processo de $n^{\circ}$ 0010045-52.2015.8.19.0028, nele o juiz recorta trechos dos depoimentos dos policiais que afirmam que o local da prisão era dominado por tráfico (p. 2), e, logo em seguida, afirma que:

verifica-se que restou cabalmente comprovada a finalidade mercantil do material entorpecente arrecadado. Deve-se registrar que os acusados foram detidos em local notoriamente conhecido como ponto de venda de drogas, dominado pela facção criminosa ADA (p. 3).

Essa categoria, tal qual a anterior, revela como algumas das justificativas para a condenação estão baseadas em estereótipos que nesse caso estão associados a regiões da cidade do Rio de Janeiro. Haber et al. (2018, p. 54) mostram que o local foi utilizado como motivação da sentença em 40\% dos casos analisados. Dentre esses casos, os autores verificaram que $65 \%$ dos locais considerados como ponto de venda de drogas eram ocorrências que aconteceram em favelas da região metropolitana da cidade (Haber et al., 2018, p. 53-54).

\subsubsection{Fundamentos das inferências: Representações}

Como adiantado na seção sobre metodologia, além de justificativas para a condenação baseadas em elementos de provas apresentados no processo, também encontramos justificativas que buscavam fundamentar o próprio raciocínio feito com base 
nessas provas. Dessa forma, os magistrados buscavam justificar porque ser possível chegar à conclusão de autoria com base na prova apresentada.

De certa maneira, a análise das categorias anteriores já revela o que fundamenta as justificativas apresentadas - reconstituição do momento do crime, estereótipos e notoriedade da prática de crime em determinado local. Entretanto, agrupamos nesta categoria as justificativas que foram explicitadas pelos magistrados.

Como exemplo, vale a transcrição de um trecho mais extenso de uma sentença. No processo no 0047053-90.2015.8.19.0213, a juíza elabora seu raciocínio a partir de certos elementos de prova (depoimento dos policiais, quantidade e variedade de drogas), para descartar a hipótese de que os réus seriam usuários, ao mesmo tempo em que constrói sua própria versão da real intenção dos acusados. A magistrada justifica seu raciocínio apontando que a hipótese dos réus não é crível e que a dela seria a mais razoável, ou seja, apontando para aquilo que meIhor corresponde à representação que ela tem do crime de tráfico e do modus operandi de traficantes:

Ora, os acusados foram flagrados de madrugada, em plena Rodovia Federal, com certa quantidade e variedade de drogas e outras substancias nocivas não sendo crível que fossem consumir todo o material entorpecente, de uma vez só. Ademais, não me parece razoável que caso realmente várias fossem as pessoas, não tivessem dividido o valor da droga entre todos, podendo comprar na cidade onde moram, sem a necessidade de se arriscar atravessando a Dutra, com todo esse material.
O caso é conhecido como "estica", pois como acima dito, traficantes compram pequenas quantidades de droga para que fossem revendidas com uma margem de lucro. Assim, não me convenceu a versão de que era para o consumo e que teria mais gente os esperando... ora, há uma despesa com o gasto de transporte que não compensaria a ida até Acari, no Rio de Janeiro. O dinheiro gasto com o combustível da moto e levando-se em consideração que tinham outras pessoas que consumir a droga, seria mais razoável que comprassem na cidade de Queimados. Por tais motivos estou convencida de que a droga tinha destinação para a revenda pelos acusados" (p. 2).

Nesta categoria, dividimos as justificativas em quatro tipos. (i) Compõem o primeiro tipo as justificativas que fundamentavam o raciocínio probatório com base na verossimilhança do descrito pelo elemento de prova. Os juízes evocam noções como atitudes típicas, caso standard, razoabilidade para justificar seus raciocínios. Na sentença do processo $n^{\circ}$ 0010557-77.2015.8.19.0014, por exemplo, os depoimentos não confirmam que o acusado foi visto em posse das drogas apreendidas, porém as testemunhas afirmam que ele fugiu da polícia. $\bigcirc$ juiz argumenta que o acusado deve ser considerado não só como o possuidor das drogas, mas também como autor do crime de tráfico, porque não é verossímil que inocentes fujam da polícia:

Diante dos depoimentos prestados, muito embora nada tenha sido encontrado diretamente com o acusado, os policiais afirmaram em juízo que viram quando o acusado correu e descartou parte da droga que foi encontrada. O próprio acusado, em seu depoimento afirmou que 
quando avistou a viatura, correu. Ora, não parece crível a este juízo que alguém que não tenha a nada a temer decida correr ao avistar a viatura da polícia [...] No entender deste juízo, se o denunciado correu ao avistar a polícia é porque estava com a droga que foi descartada e se ingressou no imóvel é porque achou que ali seria um local seguro para se esconder ( $p$. 3).

De outro modo, a verossimilhança também foi utilizada para negar a possibilidade de inferências probatórias. Por exemplo, no processo de $n^{\circ}$ 0000013-43.2015.8.19.0042, o juiz afirma que não é possível que as informações prestadas pela acusada sejam verdadeiras porque elas são inverossímeis.

(ii) Também observamos justificativas fundamentadas na experiência profissional do magistrado. ${ }^{21}$ Por exemplo, há casos em que o juiz afirma que a quantidade aprendida é típica de tráfico porque a sua experiência lhe permite afirmar que somente um traficante andaria com grande quantidade da droga apreendida; ou, que apesar da pouca quantidade, o magistrado sabe, por experiência, que os traficantes que atuam no local da prisão do réu mudaram seus métodos e atuam agora vendendo poucas quantidades. ${ }^{22} \mathrm{No}$ processo, de $n^{\circ}$ 0001548-19.2015.8.19.0038, o magistrado argumenta que:

Através de regras de experiência comum sabe-se que a quantidade de droga apreendida não poderia ser consumida por uma só pessoa. Tampouco é comum que usuários realizem uma compra de valor tão alto (p. 6).

\footnotetext{
Haber et al. (2018), Jesus (2016) e Prates (2015) também apontam para o uso de representações baseadas em um senso comum ou es tereótipos, ou do uso do repertório profissional dos juízes em suas argumentações.

2 Para o $2^{\circ}$ ver, por exemplo, o já mencionado processo nº 0038833 06.2015.8.19.0213.
}

Da mesma forma que na verossimilhança, o juiz também se vale de sua experiência para negar a possibilidade de inferir conclusões de determinadas provas, por exemplo, porque o juiz considera que a versão do réu, pela sua experiência, é comum e, por isso, falsa. No já mencionado processo de $n^{\circ}$ 0047053-90.2015.8.19.0213, a magistrada argumenta que:

Por seu turno, a versão apresentada em autodefesa por ambos os acusados, tornam-se frágeis, diante do restante do contexto probatório. Como de costume, trazem versões distorcidas e contraditórias, tendo sempre como pano de fundo a versão de que foram comprar droga em Comunidade do Rio, por ser mais barato e que apesar da quantidade, esta seria destinada ao consumo com outras pessoas.

Entretanto, esta Magistrada, pela experiência acumulada em varas criminais, inclusive, na Comarca de Queimados, onde fui titular por alguns anos, tem ciência de que ao contrário do que ocorre em algumas comunidades cariocas, aqui na Baixada Fluminense é muito comum que se compre em determinados pontos para a revenda, geralmente com preços muito mais elevados (p. 2).

(iii) Outro tipo de justificativa encontrada são as que fundamentam o raciocínio probatório a partir de textos que se pretendem técnicos, especializados em consumo e tráfico de drogas. Dessas fontes, por exemplo, os juízes retiram informações acerca da quantidade que corresponderia a uma dose única de uso de determinada droga ou daquela equivalente a uma dose suficiente para causar uma overdose:

Nesse aspecto, é esclarecedora a lição de Alexandre de Moraes e Gianpaolo Poggio Smanio, em sua obra "Legislação Penal 
Especial", da Editora Atlas, na página 137, no sentido de que, na cocaína consumida por aspiração, uma dose corresponde a 0,1g (um decigrama) da citada substância entorpecente, demonstrando que a quantidade de $34 \mathrm{~g}$ (trinta e quatro gramas), apreendida no caso em comento, equivale a aproximadamente 340 (trezentas e quarenta) doses por aspiração, o que é compatível com a mercancia ilícita de drogas (sentença do processo $\mathrm{n}^{\circ}$ 0047854-51.2015.8.19.0004, p. 2).

(iv) Por último, há justificativas que fundamentam não uma inferência específica, feita a partir de um elemento de prova, mas sim todo raciocínio feito no veredito condenatório. Os magistrados se mostram especialmente preocupados em apresentar esse tipo de justificativa quando não há uma descrição clara de que o réu foi visto vendendo drogas, afirmando que não é necessária uma prova direta da venda de drogas para que se condene por tráfico pois é possível induzir a intenção de traficar ou que o réu traficava por meio de indícios.

Por exemplo, no processo de $\mathrm{n}^{\circ} 0001346$ 72.2015.8.19.0028, o juiz justifica a condenação afirmando que é perfeitamente possível concluir com base em indícios trazidos por outras provas, como quantidade, dinheiro, local, entre outras, a intenção do réu de comercializar as drogas:

Como se sabe, na esteira da boa doutrina, respaldada pelo entendimento pacificado em sede jurisprudencial, a prova da traficância é circunstancial, isto é, deve ser extraída a partir da análise da própria conduta do acusado por crimes dessa natureza. Nessa tarefa, deve-se atentar para a natureza e quantidade de entorpecentes apreendidos (08 gramas de cocaína), sua forma de acon- dicionamento (08 sacolés pretos, prontos para venda e característicos da facção criminosa ADA), ao local e às circunstâncias da conduta (região conhecida pelo intenso comércio de entorpecentes realizado pela referida facção), além de outros detalhes que se façam relevantes e que guardem relação com o crime em tela (foi apreendido também um rádio comunicador, que servia para informar a movimentação de policiais dentro da comunidade, além da quantia de R\$30,00 em espécie) (p. 3).

Em outro processo, $\mathrm{O}$ de $\mathrm{n}^{\circ}$ 037576656.2015.8.19.0001, a magistrada justifica a própria necessidade de se condenar com base em indícios, em razão da característica falta de provas de casos que tratam de tráfico de drogas, já que nesses casos é

extremamente difícil para os agentes da lei reunirem as peças e montarem o quebra-cabeça do tráfico de entorpecentes e, assim, alcançarem os que atuam nesta nefasta prática delitiva. Daí que quaisquer provas lícitas - ou indícios destas - tornam-se imprescindíveis para, repise-se o desvendamento deste emaranhado que é o crime de tráfico de entorpecentes e, consequentemente, o convencimento final do julgador (p. 2)

Nota-se, portanto, que noções como experiência e verossimilhança permitem ao magistrado validar a sua sentença fundamentando os raciocínio probatórios com base em uma representação do que ele entende como crime de tráfico, além de permitir que ele descarte certos elementos de prova sob a justificativa de que a descrição não corresponde à representação que ele possui ou é tão comum no seu cotidiano que ele assume ser falsa. Percebe-se também que essas representações se baseiam em noções 
de senso comum e naquilo que se poderia chamar de senso comum qualificado, i.e., sua experiência como magistrado.

Por último, a justificativa que se utiliza da noção de indícios para fundamentar toda a sentença parece mostrar que os juízes reconhecem a debilidade probatória dos casos de tráfico de drogas, ao mesmo tempo em que buscam sustentar um entendimento de que ainda assim essas provas são suficientes. O que, por sua vez, parece demonstrar um compromisso com a necessidade de se condenar, mesmo que se entenda que não se possuem as melhores provas para determinar que os fatos relevantes para o julgamento aconteceram.

A pesquisa de Jesus et al. (2011, p. 80) indica a mesma percepção. $O$ trabalho mostra que magistrados e promotores afirmam em entrevistas que as provas em crimes de tráfico não são as mais seguras, porém não se pode deixar de condenar mesmo nesses casos, indicando que quando for possível afastar a incerteza, a condenação deve ser imposta. Tal posicionamento defende a condenação, ainda sob a fragilidade de provas, parece justificado em uma ideia de que o crime de tráfico é um crime grave e deve-se dar uma resposta dura a quem o pratica (Jesus et al., 2011, p. 81-85).

\subsubsection{Controle de Prova: Credibilidade dos Meios e elementos de Provas}

Nesta categoria, organizamos justificativas que fundamentam os juízos de controle de meios e elementos de prova como fontes da decisão. Importante destacar que os meios foram exclusivamente testemunhos de acusação e defesa e o depoimento do réu, enquanto os elementos consistiram nas informações retiradas dessas manifestações. Foram encontradas justificativas com dois objetivos diferentes: (i) justificar o controle de elementos de prova específicos do julgamento. (ii) justificar o controle genérico de meios de prova, avaliando não o meio de prova que serviu como fonte específica para o julgamento, mas o "gênero" ao qual ele pertence.

(i) O primeiro tipo de justificativas pode ser dividido pelo tipo de controle feito, seja negativo - justificativa para descarte de elementos de prova -, seja positivo - justificativa para o uso de elementos de prova. Identificou-se que o controle negativo nas condenações se limitou aos testemunhos de defesa ou do réu e se baseava tanto na comparação de determinado elemento de prova com o conjunto probatório, quanto na qualidade das informações do testemunho de defesa. Dessa forma, informações dos testemunhos ou do depoimento do acusado são descartadas sob a justificativa de que não há outros elementos que as sustentem ou se estão em contradição com os outros elementos, ainda que seja comum que o outro único elemento probatório sejam informações dadas pelos policiais. Por exemplo, no processo de $n^{\circ}$ 0008465-59.2015.8.19.0004, o depoimento do réu foi descartado sob a alegação de que ele estava isolado no conjunto probatório. ${ }^{23}$

Já a aplicação do controle positivo foi observada exclusivamente para os testemunhos de acusação. As justificativas se fundamentam tanto na comparação com outros elementos probatórios, apontando que eles davam suporte às declarações ou não traziam informações relevantes o suficiente para diminuir a credibilidade dos testemu-

23 Lemgruber e Fernandes (2015) apontam casos em que o depoimento do réu é descartado sob a mesma justificativa, mas o conjunto probatório consiste somente na palavra do policial e na droga apreendida. 
nhos $^{24}$, quanto na coerência interna desses depoimentos, e.g., não apresentarem contradições e serem ricos em detalhes. ${ }^{25}$

Nota-se que esses fundamentos se apresentam em termos de coerência interna (depoimentos harmônicos) e contextual (declarações possuem suporte probatório). Com relação à coerência interna, entretanto, um olhar mais atento revela que os magistrados tendem a tolerar as mesmas inconsistências nos testemunhos dos agentes de segurança que eles utilizam como justificativa para descartar testemunhos de defesa. Por exemplo, o processo $n^{\circ}$ 0012491-82.2015.8.19.0204, no qual o juiz chega a afirmar, tratando dos testemunhos dados pelos policiais, que

como é de elementar sabença, pequenas divergências a respeito de circunstâncias de somenos importância não desnaturam o núcleo das declarações e, longe de invalidar a prova, dão maior credibilidade às testemunhas, por trazerem a certeza de não se estar em presença de depoimentos forjados (p. 4).

Quanto à coerência contextual, Jesus (2015, p. 223) encontra justificativas parecidas para descartar as testemunhas de defesa, como compará-las com o acervo probatório, quando esse acervo é somente o depoimento de policiais.

As observações de Prates (2013) em audiências de instrução trazem informações interessantes sobre a dinâmica da inquirição das testemunhas cujo uso ou não do conteúdo do depoimento como fonte para o julgamento será depois justificado na sentença. Com relação aos depoimentos dos policiais, a autora chama atenção para práti-

\footnotetext{
${ }^{24}$ Para o $1^{\circ}$ exemplo ver o processo de $n^{\circ} 0000919-07.2015 .8 .19 .0083$, o $2^{\circ} \mathrm{n}^{\circ}$ 0001181-85.2015.8.19.0202.

${ }^{25}$ Para o $1^{\circ}$ exemplo, ver processo $n^{\circ} 0003927-49.2015 .8 .19 .0064$, para o $2^{\circ}$, o de $n^{\circ} 0002345-02.2015 .8 .19 .0068$
}

cas que buscam indicar para o policial o que ele deveria dizer para que o réu possa ser condenado e a tolerância com defeitos nesses depoimentos. A autora destaca a leitura da denúncia, a passagem de informações e a justificação das lacunas nos depoimentos e justificativas para o esquecimento ou contradições como o lapso de tempo entre a ocorrência e o testemunho (Prates, 2013, p. 91). Segundo a autora, há uma seleção daquilo que seria a boa e má informação, sendo a boa aquilo que corrobora a denúncia (Prates, 2013, p. 110-111).

(ii) O segundo tipo de justificativas também pode ser dividido da mesma maneira, sendo o controle positivo a presunção de uma credibilidade das informações trazidas por um meio de prova e o negativo a presunção de descrédito.

O controle positivo é justificado por três espécies de motivos. Há os normativos, que justificam o uso dos testemunhos de agentes de segurança, por conta de uma norma construída pela doutrina e jurisprudência que determina a presunção de veracidade de seu conteúdo. Por exemplo, no processo $\mathrm{n}^{\circ}$ 0013933-12.2015.8.19.0066, o magistrado menciona dois julgados do TJ-RJ e a súmula 70 do mesmo tribunal para justificar que a condenação feita com base no depoimento dos agentes de segurança que prenderam o acusado é legitima.

Há os pragmáticos, que afirmam a necessidade prática de usar esses testemunhos, pois normalmente os meios de provas nos casos de tráfico de drogas são escassos. Dessa forma, caso entenda-se que esse meio de prova não pode ser admitido, seria impossível condenar qualquer pessoa. A sentença do processo de $n^{\circ}$ 0022669-20.2015.8.19.0001 é exemplificativa das justificativas baseadas nesses motivos: 
Repise-se que as palavras dos policiais que efetuaram a prisão merecem tanto crédito quanto a de qualquer outro cidadão, haja vista que nada foi trazido aos autos capaz de diminuir a força de suas declarações ou afetar-lhes a veracidade [...] É cediço que com o afã de inocentar-se de uma acusação penal, todo ser humano procura argumentos convincentes, mas a função precípua da Justiça é buscar a verdade. E um dos recursos utilizados para tanto é a análise da narrativa das pessoas envolvidas, perscrutando-se a sua coerência e ressonância com os demais elementos dos autos. Não se pode ignorar a complexidade e a magnitude que o tráfico de entorpecentes alcançou nestes últimos tempos em nossa sociedade, sendo certo que nunca se viu tanta brutalidade cometida pelos que o praticam ou o acobertam. Vale dizer que estes engendram todos os seus esforços para livrarem-se das garras da lei, aproveitando-se, ainda, de ser extremamente difícil para os agentes da lei "reunirem as peças e montarem - quebra-cabeça" do tráfico de entorpecentes e, assim, alcançarem os que atuam nesta nefasta prática delitiva. Daí que quaisquer provas lícitas - ou indícios destas - tornam-se imprescindíveis para, repise-se o desvendamento deste emaranhado que é o crime de tráfico de entorpecentes e, conseqüentemente, o convencimento final do julgador. Portanto, vale dizer, não se podem desprezar quaisquer elementos constantes nestes autos, principalmente os mais remotos no tempo, na medida em que foram obtidos no calor dos acontecimentos (p. 2).

Encontramos também o que chamamos de motivos idealistas que defendem o pa- pel do policial enquanto agente público honesto, desinteressado, aliado a um conjunto de consequências negativas para o funcionamento das instituições, caso deixe de se entender presumida a verdade nas palavras dos policiais. Por exemplo, no processo $n^{\circ}$ 0000130-54.2015.8.19.0003, argumenta o juiz que acolher a tese da defesa de que não se pode condenar somente com base na palavra dos policiais é inadmissível, pois o Estado não se faria representar por agentes que não fossem honestos:

Não há, por outro lado, qualquer indício ou evidência de que os policiais mentiram em juízo para incriminar gratuitamente os acusados, nada havendo que desabone suas condutas. Assim, os seus depoimentos são válidos e aptos a embasar a condenação, pois não é razoável conceber que o Estado se faz representar por agentes indignos de credibilidade. Aliás, pensar de outra forma seria subverter por completo a presunção de legalidade (0000130-54.2015.8.19.0003, p.1).

Jáno processo n0002900-08.2015.8.19.0007, o juiz é mais incisivo ao afirmar as consequências negativas de não se admitir o depoimento dos policiais como meio de prova:

Vale dizer, se a autoridade judiciária não der crédito aos agentes policiais quando os mesmos depõem com firmeza, está decretada a falência do sistema. Ademais, os policiais são servidores públicos e que, até que se prove o contrário, se presumem verdadeiras suas declarações, havendo, deste modo, presunção juris tantum de idoneidade. Até porque, não há sentido no Estado credenciar seus policiais para o combate ao crime e depois lhes negue crédito as suas versões (p. 6) 
Outro exemplo é o processo no: 000438681.2015.8.19.0054:

A Justiça não pode simplesmente considerar inidôneos ou suspeitos os depoimentos de policiais, baseando-se em sua condição funcional, pois, em assim sendo, instalar-se-ia o caos social. Ressalte-se, por derradeiro, que na qualidade de agentes da autoridade pública, seus atos gozam de presunção de legitimidade, somente ilidida com robusta prova em contrário. (p. 3).

Já o controle negativo, dirigido ao depoimento do réu e testemunhas de defesa, se baseia em uma desconfiança que parte da própria posição que ocupam no julgamento. As testemunhas de defesa não seriam confiáveis, seja porque nos casos de tráfico de drogas elas se sentiriam ameaçadas e não falariam a verdade, seja porque são parentes ou próximos do acusado e, portanto, enviesados. No processo de $n^{\circ} 0001917-$ 37.2015.8.19.0030, por exemplo, o juiz se utiliza desses dois tipos de justificativa para descartar os testemunhos de defesa como meio de prova:

As testemunhas [...] são parentes do réu, e diante de tal relação, dificilmente externariam qualquer manifestação contrária aos interesses do réu [...]. Análise semelhante ao do argumento exposto acima, deve ser feita do depoimento da testemunha de defesa [...], dono do bar onde o réu foi preso, visto que não se poderia esperar conteúdo diferente dos relatos prestados pelas testemunhas [...], vez que se trata de pessoa que possui comércio no local e, como se sabe, poderia sofrer represália caso, em Juízo, afirmasse fato que desabonasse a conduta do réu. Ademais, é de conhecimento notório

o fato de que moradores de locais onde ocorre tráfico de drogas, caso venham a falar em Juízo, são intitulados por X-9 (delator) pelos traficantes, perseguidas e até mortas, por conta dos relatos que fazem (p. 4).

Quanto ao réu, justifica-se o não uso do seu depoimento sob o argumento de que ele possui interesse em ser inocentado e presumidamente mentiria, uma vez que a própria lei o protege por não lhe impor consequências se ele mentir em juízo. ${ }^{26}$

As justificativas para o controle de provas registradas nas sentenças também foram encontradas por outros trabalhos. Carvalho e Weigert (2018, p. 66-67), estudando um processo em que se discutia a prática do crime de tráfico de drogas, destacam que as testemunha de defesa foram descartadas pelo juiz em razão da sua suposta parcialidade que se fundamentava no fato dela ser amiga da mãe do acusado. Isto sem que a acusação tivesse contraditado a testemunha ou apresentado qualquer outra objeção à credibilidade do seu depoimento.

Os autores também analisam o controle de credibilidade realizado pelo magistrado em relação aos policiais, que teria se baseado na presunção de veracidade do depoimento dos policiais, em razão da fé pública (Carvalho \& Weigert, 2018, p. 51). Jesus (2015, p. 233/234), encontra também justificativas que buscam deslegitimar o uso do réu como meio de prova ao associar a sua palavra à mentira. Em contraposição, a autora encontra as mesmas justificativas corporativistas e idealistas para se dar crédito à polícia, argumentando que dar crédito à polícia equivaleria a dar crédito à justiça e ao associar a palavra do policial à verdade

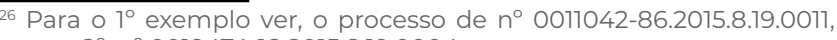
para o $2^{\circ}: n^{\circ} 0019474-18.2015 .8 .19 .0004$. 
As pesquisas mostram que essa relação de dependência e presunção de veracidade com as palavras dos policiais perpassa todo o processo ao longo do seu percurso no sistema de justiça criminal. São os policiais os agentes do sistema de justiça que definem aqueles que irão responder um processo criminal já que são eles os responsáveis por ter o primeiro contato com o sujeito perseguido (Paes, 2008, p. 183 apud Couto et al., 2017, p. 406) e é com base em seu depoimento que delegados instauram um inquérito e promotores oferecem a denúncia contra o acusado (Grilo et al. 2011; Jesus et al. 2011).

É curioso notar que esses trabalhos mostram que as justificativas apresentadas pelos operadores das diferentes fases de um processo para utilizarem-se das palavras dos policiais são semelhantes: os policiais, por trabalharem no combate ao crime, sabem mais do que os outros operadores sobre as diversas formas desse fenômeno social, o que legitima seu relato como a fala de um especialista (Jesus, 2015, p. 165). Apesar disso, há operadores que reconhecem a precariedade de processos conduzidos com base somente no depoimento de policiais, mas se justificam em razão de questões pragmáticas, como a dificuldade de se arrolar outras testemunhas (Jesus 2015; Prates, 2015).

Todavia, como já destacamos, esse não é um fenômeno recente. Garcia (2005, p. 63) e Raupp (2005, p. 61, apud Campos, 2015, p. 192) analisando processos judiciais sob a antiga lei de drogas, já haviam percebido que a maior parte da discussão no processo concentrou-se na confiabilidade do testemunho dos policiais que prenderam o acusado.

\section{- Sentenças Absolutórias:}

Tendo apresentado os resultados das sentenças condenatórias, passaremos a tratar das justificativas encontradas nas sentenças absolutórias, comparando as diferenças e semelhanças entre as categorias encontradas nos dois tipos de sentença.

\subsubsection{Inferências probatórias:}

\section{A) Descrição da Prisão:}

Nas sentenças absolutórias, encontramos justificativas baseadas em fundamentos semelhantes aos apresentados nas condenações e na inexistência desses mesmos fundamentos.

O primeiro tipo de justificativa fundamenta a absolvição em informações que descrevem o momento da prisão do acusado e permitem concluir que o acusado não traficava, essencialmente com base em dois fundamentos. (i) Porque não foi possível demonstrar que ele era o dono das drogas apreendidas, como por exemplo, no processo de $n^{\circ}$ 0028479-13.2015.8.19.0021:

Os Policiais Militares ainda frisaram que estavam apenas os dois no local e que com o réu nada foi encontrado. As circunstâncias da prisão, aliadas ao fato de o réu não ter sido flagrado na posse de entorpecentes, torna absolutamente duvidosa a acusação de que ele estaria traficando drogas (p. 2).

(ii) Porque os testemunhos comprovam que ele não era o possuidor das drogas. No processo n`0108580-37.2015.8.19.0021, o réu é inocentado porque os depoimentos comprovam que ele estava apenas trabalhando e as drogas pertenciam, na verdade, ao corréu:

Nesse sentido, não é possível atribuir a autoria dos fatos ao acusado, uma vez que com o mesmo nada foi encontrado e a dinâmica do delito aponta que o mes- 
mo exercia a atividade de mototáxi e apenas realizava o transporte do réu Leandro que faleceu na ocasião, o qual estava na posse das drogas (p. 3).

Já o segundo tipo de justificativa fundamenta-se na impossibilidade dos elementos comprobatórios que descrevem a prisão em demonstrar que o réu traficava ou tinha intenção de fazê-lo, porque não há testemunhos que relatem que o acusado vendia drogas ou porque se existem, eles não são confiáveis por apresentarem inconsistências. Por exemplo, na sentença do processo de nº 0002361-10.2015.8.19.0050, o juiz assevera que os depoimentos foram capazes de provar a posse, mas não foram capazes de indicar que as drogas se destinavam ao tráfico:

Assim se afirma porque, se de um lado, os policiais militares efetivamente, ao que parece, encontraram substância entorpecente no interior da casa do acusado, entre as almofadas do sofá, conforme revelado, lado outro não se comprovou que o acusado vinha se dedicando ao comércio ilícito de drogas [...]. Verifica-se que o acusado não foi surpreendido ao longo da prática do comércio de drogas, valendo destacar que os agentes da lei, de posse daquelas informações, poderiam ter preparado diligência de observação de modo a comprovar a notícia recebida, inclusive, com abordagens aos usuários que eventualmente adquirissem drogas com o réu, o que não fizeram (p. 3).

Haber et. al. (2018, p. 49) apontam a importância que a descrição do flagrante parece ter como justificativa para absolvição. A categoria desenvolvida pelos autores chamada de condições em que se desenvolveu a ação foi encontrada como justificativa para a absolvição em 96\% das sentenças. Portanto, percebe-se que a descrição do flagrante também é uma justificativa recorrente para fundamentar a absolvição de acusados por tráfico de drogas. Entretanto, para além de justificativas que se baseiam efetivamente em descrições que buscam reconstruir os fatos relevantes para o julgamento, tal como encontramos nas sentenças condenatórias, aqui notamos que a ausência dessas descrições também é utilizada como argumento decisório.

\section{B) Materiais Apreendidos}

Como na categoria anterior, nas sentenças absolutórias, as justificativas desta categoria também se fundamentam na ausência de elementos probatórios, ou seja, na ausência dos materiais mencionados nas sentenças condenatórias como justificativa da autoria do réu. Além disso, encontramos argumentos para a absolvição cujo fundamento era a pequena quantidade de drogas apreendidas. O processo n 0003738-65.2015.8.19.0066 exemplifica as justificativas agrupadas nessa categoria:

Além disso, os critérios do art. 28 , § $2^{\circ}$, da Lei $n^{\circ} 11.343 / 06$ favorecem o réu, pois [...] não portava grande quantidade de droga e não foram encontrados dinheiro, materiais para endolação ou outro elemento que denotasse atos de mercancia de drogas. A pequena quantidade de entorpecente e as circunstâncias da prisão não permitem concluir que ele estava traficando drogas (p. 7).

Haber et. al. (2018, p. 48) apontam que os aspectos materiais foram observados em poucas sentenças absolutórias: argumentos baseados na natureza da substância foram encontrados em menos de $1 \%$ das sentenças e os baseados na quantidade da substância 
apreendida em somente 8,8\%. Porém, esses dados não permitem concluir sobre a frequência das justificativas que agrupamos nessa categoria porque em Haber et al. (2018) a ausência dos objetos não foi contabilizada. ${ }^{27}$

\section{C) Características do Acusado}

No banco de dados pesquisado, não é comum encontrar em absolvições, tal como nas sentenças condenatórias, justificativas baseadas em características do acusado. Haber et al. (2018) apontam que argumentos baseados em condições sociais e pessoais do acusado apareceram em 5,8\% das sentenças e os baseados em antecedentes em 4,8\%.

Nas sentenças absolutórias, encontramos somente justificativas baseadas na primariedade. Por exemplo, no processo $n^{\circ}$ 0000812-64.2015.8.19.0017 discute-se a prática de tráfico entre dois acusados. Uma das justificativas apresentadas pelo juiz para inocentar um dos réus é a sua primariedade, que indica verossimilhança na sua alegação de que estava voltando do trabalho e foi presa por engano. Esse é um processo interessante, porque um dos argumentos para se condenar o outro acusado foi justamente "maus antecedentes".

Percebe-se que, como nas condenações, as justificativas dessa categoria também se baseiam em estereótipos, porém com o sinal trocado. Tal dado aponta na direção de que os juízes efetivamente parecem considerar que quem o acusado é pode ser usado como um elemento válido para justificar uma condenação por tráfico.

7 "Nesta seção foram registradas todas as referências à qualidade/es pécie de droga (maconha, cocaína, crack ou outras) encontrada com os réus ou perto deles, e, nas sentenças em que foi discriminada a quantidade encontrada, foram registrados os quantitativos em gramas" (Haber, 2018, p. 17).

\section{D) Local da prisão}

Apesar de Haber et al. (2018) apontarem que o local foi encontrado em 19,6\% dos processos da base de dados, em nossa pesquisa encontramos somente dois casos em que o local foi usado como justificativa para absolvição. Os dois processos utilizam a informação de que local da prisão é notório por tráfico da mesma maneira. Na sentença do processo $n^{\circ}$ 0005481-03.2015.8.19.0037, o juiz fez uso da notoriedade do local da prisão como um local de tráfico para inocentar o réu, já que este não foi visto traficando ou em posse das drogas, não haveria como imputá-las ao acusado, podendo pertencer a qualquer um:

De fato, não se sabe, com a necessária certeza, se a droga foi ali deixada pelo acusado, ou se foi depositada no local por outra pessoa, já que os policiais informaram que o local é conhecido como ponto de venda de drogas e que diversas pessoas fugiram do local no momento da chegada da polícia (p. 3). ${ }^{28}$

Nessas sentenças, os juízes elaboram uma argumentação oposta à que encontramos na categoria análoga condenações que praticamente impossibilita o uso da notoriedade do local da prisão como local de tráfico para justificar uma condenação.

Ministério Público pediu a absolvição

Essa é a categoria com a justificativa mais simples, já que o seu fundamento é somente o pedido de absolvição realizado pelo Ministério Público. Basicamente, o magistrado utiliza como argumento a manifestação do Ministério Público em favor do acusado, alegando a desclassificação do delito de tráfico

O outro processo é o de nº000919-07.2015.8.19.0083. 
para o de uso ou a falta de provas para uma condenação. 29

\subsubsection{Fundamentos das inferências: Representações}

Nas sentenças absolutórias, foi encontrado somente um tipo de justificativa para as inferências probatórias, a verossimilhança. Encontramos essa justificativa usada tanto em um sentido positivo, quanto negativo. Quanto ao sentido positivo, ela foi usada para justificar a possibilidade de se concluir um fato a partir do elemento de prova e pode ser exemplificado pelo processo de $\mathrm{n}^{\circ}$ 0000812-64.2015.8.19.0017, usado também como exemplo na categoria Características do Acusado. Nele, o magistrado conclui que é possível que seja verdade a alegação da ré de que estava somente voltando do trabaIho em razão de ser verosímil, uma vez que a ré estava usando uniforme e era primária. Já com relação ao sentido negativo, a verossimilhança foi usada como justificativa para a impossibilidade de que se chegue a uma determinada conclusão com base em determinados elementos de prova. No processo de $n^{\circ}$ 0022015-12.2015.8.19.0008, por exemplo, o juiz descarta a possibilidade de concluir pela autoria com base no depoimento dos policiais porque ele descreve uma situação inverossímil.

Nota-se que as justificativas agrupadas nesta categoria assumem a mesma função que nas sentenças condenatórias, pois permitem ao magistrado validar sua sentença fundamentando sua decisão em representações da realidade, ao mesmo tempo em que descarta provas sob a justificativa de que a descrição fornecida por elas não corresponde à sua representação.

\subsubsection{Controle de Prova: Credibilidade dos Meios e elementos de Provas}

Classificamos as justificativas nesta categoria da mesma maneira que nas sentenças condenatórias: (i) aquelas cujo objetivo de justificar o controle de elementos de prova específicos do julgamento e (ii) aquelas cuja finalidade é o controle genérico de meios de prova.

(i) O controle negativo no primeiro tipo se direcionou aos testemunhos de acusação, principalmente ao depoimento dos policiais. Como nas condenações, encontramos justificativas fundamentadas na ausência de informações relevantes, i.e., considerou-se que o depoimento não trazia informações que possibilitam um juízo de certeza. Também encontramos justificativas baseadas ou na comparação do testemunho com o conjunto de elementos de provas, sendo sua informação identificada como contraditória, ou porque o conjunto não é capaz de sustentar a alegação que se busca afirmar com base nesse elemento específico.30

O processo $n^{\circ}$ 0011534-02.2015.8.19.0004 exemplifica esse tipo de controle. Nele, o juiz descarta as informações dos policiais como elementos de prova em razão de lacunas desses depoimentos e porque uma das testemunhas se limitou a repetir o que foi dito pelo Ministério Público:

O policial DILMAR não relatou com firmeza o que teria sido apreendido em poder do adolescente BRUNO. O policial Paulo Roberto, por sua vez, limitou-se a narrar os fatos da denúncia, sem apresentar nenhum detalhe que não constasse da peça inicial (p. 3).

\footnotetext{
$\overline{30}$ Para o $7^{\circ}$ exemplo, ver o processo n ${ }^{\circ} 0022234-43.2015 .8 .19 .0002$, para
} o $2^{\circ}: n^{\circ} 0004256-50.2015 .8 .19 .0003$ 
Aqui é preciso destacar uma observação. Mesmo ao fazer um controle negativo dos testemunhos dos agentes de segurança, os juízes não deixam de afirmar a condição especial que estes testemunhos possuem. É comum que eles afirmem reconhecer a presunção de veracidade dos testemunhos dos agentes de segurança, ao mesmo tempo em que dizem que no caso em questão havia elementos capazes de diminuir, até anular, esta presunção. ${ }^{31}$

Já o controle positivo se direcionou aos testemunhos de defesa e depoimento do réu, tendo por fundamento a coesão das provas. $O$ juiz entende que os testemunhos de defesa e do réu são coerentes ou estão sustentados em outros elementos de prova, como no inquérito policial ou na quantidade das drogas. A sentença do processo $n^{\circ}$ 0004854-70.2015.8.19.0078 é exemplificativa do controle positivo. Nela, o magistrado justifica o uso do testemunho de defesa e do acusado tanto porque eles são coerentes entre si, quanto porque eles estão de acordo com outros depoimentos dados no inquérito, mas que não foram repetidos em juízo.

Comparando com os resultados encontradas nas sentenças condenatórias, percebemos que as justificativas apresentadas pelos juízes são as mesmas - coerência interna e externa - para descartar ou utilizar as informações obtidas em juízo. Todavia, nota-se que os elementos de prova sujeitos ao controle positivo e negativo se invertem. Ao contrário das absolvições, nas condenações eram os testemunhos de acusação que estavam sujeitos ao controle positivo e os testemunhos de defesa e o depoimento do réu sujeitos ao controle negativo.

Parece autoexplicativo que essas posições se invertam a depender do resultado do julgamento, justamente porque a fragilidade dos elementos probatórios da acusação justifica o veredito absolutório e a força dos mesmos elementos justificam uma condenação. Entretanto, não foi encontrado um paralelo nos casos de absolvição à tolerância com as contradições e lacunas dos depoimentos dos policiais encontrada nas sentenças condenatórias. Esse dado parece indicar que é preciso defeitos muito mais explícitos nos depoimentos de acusação para que eles sejam descartados do que nos de defesa, especialmente ao verificar que mesmo quando os juízes descartam o depoimento dos policiais, eles explicitam que não se contrapõem ao entendimento de que esses depoimentos gozam de uma presunção de veracidade.

(ii) No segundo tipo de justificativas, encontramos somente o uso do controle negativo. Os argumentos tinham como objetivo descartar o local da prisão e informações extrajudiciais como meios de prova.

Com relação ao local da prisão, em um processo, $\mathrm{n}^{\circ}$ 0201738-12.2015.8.19.0001 o magistrado afirma que não se pode concluir do local da prisão a prática de tráfico porque não seria possível retirar qualquer conclusão dessa informação:

Por último, cumpre acrescentar que apesar do réu residir em comunidade dominada por tráfico de entorpecente, que estivesse em local conhecido como boca de fumo', não há como impor decreto condenatório tão somente com base em mera possibilidade. O sentido da regência do direito processual penal pelo princípio da verdade real destina-se à formação de verdadeiro e confiante convencimento do juízo (p. 2). 
Quanto às informações extrajudiciais, elas não possuiriam valor probatório porque haveria uma obrigação de se decidir somente com elementos probatórios apresentados durante o julgamento. Por exemplo, a sentença do processo n ${ }^{\circ} 0011534-$ 02.2015.8.19.0004:

Acerca da suposta confissão do acusado no momento da prisão, é importante ressaltar que, se nem mesmo a confissão feita perante a autoridade policial durante o inquérito, devidamente documentada, é capaz de, sozinha, fulcrar uma condenação, por se tratar de mero indício, muito menos ainda a chamada "confissão informal", decorrente de conversa no momento da abordagem, sem qualquer oportunidade de defesa, de documentação, ou mesmo da prévia advertência constitucional quanto à desobrigação da autoincriminação (p. 3).

Contrapondo o controle de meios de prova encontrados nas sentenças absolutórias e condenatórias, nota-se que praticamente não há paralelos. Os meios de prova sujeitos ao controle são completamente diferentes e não há nenhum argumento a favor da presunção de veracidade de depoimentos de defesa. O que os resultados encontrados parecem apontar é para a existência de uma divergência interna dentro do Tribunal de Justiça do Rio de Janeiro acerca de quais meios de prova podem ou não sustentar uma decisão judicial. É preciso lembrar que os mesmos meios de prova descartados em sentenças absolutórias são utilizados como fonte de informações para as inferências probatórias encontradas nos casos de condenação.

\section{CONCLUSÃO}

Ao final da pesquisa, podemos perceber quais elementos parecem ser considerados como necessários para justificar a decisão do magistrado. Nesse aspecto, observamos a presença de três grandes grupos de categorias de justificativas: (i) inferências probatórias; (ii) fundamentos da inferência probatória e (iii) controle de provas. Esses grupos, assim como as categorias que os compõem, foram observados tanto em sentenças condenatórias quanto nas absolutórias, o que parece revelar que, em algum grau, há uma uniformidade no procedimento de justificação da decisão judicial, especialmente se observarmos, como já foi apontado, que as justificativas que compõem o primeiro grupo, inferências probatórias, foram observadas em outros trabalhos.

Com relação ao primeiro grupo (i), podemos observar que as justificativas se dividem entre as que fundamentam a comprovação da posse de drogas e a autoria de tráfico. Observamos que as justificativas direcionadas à comprovação ou não da posse fundamentam-se exclusivamente na reconstrução do momento do flagrante por meio de documentos oficiais, vídeos, confissão do acusado, mas principalmente de testemunhos. A mesma operação de reconstrução é encontrada para justificar a autoria, ainda que não seja a única justificativa.

Tal processo de justificação é bastante similar ao descrito por Foucault (2013) como o objetivo do procedimento judicial de construção da verdade jurídica inquisitorial: reconstituir o momento do crime em juízo de tal modo que o juiz decida como se tivesse presenciado o crime.

Assim, a categoria Descrição do Flagrante aparece ao lado da Confissão do Acusado como a principal justificativa nas sentenças analisadas, seja para condenar ou absol- 
ver. ${ }^{32}$ Como descrevemos, uma das justificativas para a absolvição é justamente que a reconstrução não apontou o acusado como possuidor das drogas, ou não o descreveu vendendo drogas ou com alguma atitude da qual se pudesse depreender a intenção de fazê-lo, ou ainda pela descrição se conclui que ele é inocente.

Ao analisar os elementos probatórios que sustentam a Descrição do Flagrante, vimos que o principal são as informações trazidas pelos testemunhos dos agentes de segurança que realizaram a prisão do acusado. Consequentemente, o testemunho dos policiais que prenderam o acusado em flagrante, especialmente quando este não confessa ou quando a confissão é informada pelo próprio policial nos casos de confissão extrajudicial, se mostra uma peça importante para embasar a decisão, como já apontaram outros trabalhos mencionados anteriormente.

Já quanto às outras categorias pertencentes ao primeiro grupo, os resultados se mostram semelhantes aos problemas da (a) falta de parâmetro e (b) do uso de estereótipos já elencados pela literatura. (a) As pesquisas mostram que não há um parâmetro na aplicação dos critérios do $\S 2^{\circ}$ do artigo 28 da lei de drogas, especialmente, com relação à quantidade de drogas apreendidas que será considerada como indicativo de tráfico. As justificativas encontradas apontam no mesmo sentido, já que os resultados mostram que até mesmo a pouca quantidade de drogas, assim definida pelo próprio juiz, pode ser usada como justificativa de tráfico. O fenômeno da falta de parâmetro no uso da quantidade como argumento para condenação também é indicado pelo uso

\footnotetext{
32 Como dito acima, na base de dados usada como fonte de dados para essa pesquisa, Haber et al. (2018) mostraram que as justificativas baseadas no contexto da prisão do acusado foram encontradas em aproximadamente $64 \%$ das sentenças condenatórias e $92 \%$ das em aproximadich absolutórias.
}

de textos técnicos como fundamento para raciocínios feitos com base nesse tipo de justificativa.

Além disso, o mesmo fenômeno ocorre com outras características das drogas e o dinheiro apreendido. Não foi apresentado um parâmetro para o que se deve considerar como natureza, variedade e acondicionamento característico de tráfico, nem para a quantidade de dinheiro apreendido.

(b) As justificativas baseadas em estereótipos, apesar de não serem comuns nas sentenças que fazem parte da base de dados desta pesquisa, foram observadas tanto para condenar quanto para absolver os acusados. Ainda, o mesmo fenômeno é observado na categoria Local. O uso da suposta notoriedade da prática de tráfico no local da prisão dos acusados, associada à descoberta de Haber et al. (2018) de que, quando explicitado, a maioria dos locais considerados como notórios pela prática de tráfico são favelas, mostra que os juízes parecem entender como justificativas válidas considerações sobre características socioeconômicas dos acusados.

Esses resultados reforçam a ideia presente na literatura de que os critérios legais permitem uma maior discricionariedade dos juízes para decidir com base em seu subjetivismo e em características subjetivas do acusado.

O uso de noções estereotipadas também foi percebido no segundo grupo de categorias (ii), os fundamentos das inferências. As justificativas desse grupo mostram como os magistrados fazem uso de representações sobre o crime de tráfico baseadas em senso comum (verossimilhança e experiência pessoal) ou em um senso comum qualificado (experiência enquanto magistrado) seja 
para justificar as conclusões que eles chegam a partir dos elementos de prova e descartar outras conclusões possíveis, seja em condenações ou absolvições.

Logo, parece que a imposição de critérios para a distinção entre os tipos penais não parece ter sido capaz de impedir que a distinção aconteça de maneira subjetiva e baseada em estereótipos.

Ainda, identificamos nesse grupo justificativas voltadas a fundamentar o veredito condenatório como um todo. Nestas, percebemos que os magistrados reconhecem um certo grau de fragilidade do conjunto probatório dos casos de drogas, mas justificam sua sentença em razão da possibilidade de se condenar com base em indícios e em razão da própria necessidade de se condenar, já que se eles não utilizassem as provas normalmente disponíveis não seria possível elaborar um veredito condenatório.

Por último, o terceiro grupo de categorias (iii) mostra como nesse cenário de poucas provas, os magistrados buscam legitimar o meio de prova mais recorrente e as informações que ele fornece como fontes para a sua decisão.

Encontramos justificativas normativas, pragmáticas e idealistas cujo objetivo era defender condenações cuja única prova era o testemunho dado pelos agentes de segurança, seja apontando que eles não podem ser descartados a priori, seja apontando que a eles deve ser conferida uma presunção de veracidade, seja ainda listando consequências negativas do entendimento de que eles não podem ser usados como fonte do julgamento, destacando-se as que listam a impossibilidade de condenação e falência do sistema de justiça.
Além disso, percebemos que há indícios de uma maior tolerância a fragilidades na consistência do conteúdo dos testemunhos dos policiais com relação aos testemunhos de defesa e ao depoimento do réu. A construção da legitimidade dos policiais parece ser tão forte dentro da instituição judiciária, que até mesmo quando é exercido um controle negativo específico sobre esses elementos de prova, os juízes precisam explicitar que eles não refutam sua legitimidade.

Jesus et. al. (2011), Jesus (2015) e Prates (2013) mostram que os outros operadores desse sistema assumem uma posição ambígua com relação à força da palavra do policial. Ainda que reconheçam a precariedade de se fundamentar um procedimento criminal somente com base em depoimentos dos policiais, admitem que esses agentes possuiriam um saber privilegiado sobre o fenômeno da criminalidade e por isso dão seguimento aos processos com base em seus depoimentos, justificando sua deferência aos policiais como se eles fossem especialistas (Jesus, 2015, p. 221).

Essa posição é ilustrada pelas pesquisas que mostram o baixo grau de revisão que os procedimentos iniciados por flagrante dentro do sistema de justiça criminal brasileiro, assim como pela rapidez com que são julgados, quando comparados à média geral e também pelo baixo grau de revisão que esses procedimentos apresentam (Azevedo \& Vasconcelos, 2011; Costa \& Júnior, 2016.; Couto et. al., 2017; Jesus et. al., 2011; Lemgruber e Fernandes, 2015; Misse, 2010; Vargas, 2012).

Por fim, acreditamos que em um cenário de contexto probatório fraco, mas entendido como um caso pronto em razão do início por flagrante, embasados por uma legislação que instituiu critérios subjetivos 
e compartilhando uma noção de que o papel do juiz é condenar sempre que possível, juízes buscam preservar o principal e mais comum meio de prova dos julgamentos de drogas: o depoimento dos policiais. Para tanto, justificam sua sentença em aspectos que não dependem de produção probatória, como estereótipos, ou de parâmetros, como quantidade e dinheiro.

\section{REFERÊNCIAS}

Alvarez, M. C., \& Campos, M. S. (2017). Pela metade: Implicações do dispositivo médico-criminal da "Nova" Lei de Drogas na cidade de São Paulo. Tempo soc., 29(2), 45-74.

Azevedo, R. G., \& Vasconcellos, F. B. (2011). O inquérito policial em questão: situação atual e a percepção dos delegados de polícia sobre as fragilidades do modelo Brasileiro de investigação criminal. Soc. estado., 26(1), 59-75.

Boiteux, L. (Coord.). n/a et al. (2009). Relatório de Pesquisa "Tráfico de Drogas e Constituição". Série Pensando o Direito. Universidade Federal do Rio de Janeiro/Universidade de Brasília. Rio de Janeiro/Brasília, RJ/ DF, Brasil.

Brasil. (2006). Decreto-lei $n^{\circ} 11.343$, de 23 de agosto de 2006. Recuperado em setembro, 2018, e fevereiro, 2019, de http://www.planalto.gov.br/ccivil_03/_ ato2004-2006/2006/lei/l11343.htm.

Brasil. (2019) Levantamento Nacional de Informações Penitenciárias, atualização julho de 2017. Organização: Marcos Vinícius Moura. Brasília: Ministério da Justiça e Segurança Pública, Departamento Penitenciário Nacional.

Brasil. (2003). Tribunal de Justiça do Rio de Janeiro. Súmula número 70.

Campos, M S. (2015). Pela metade: as principais implicações da nova lei de drogas no sistema de justiça criminal em São Paulo. Tese de Doutorado, Universidade de São Paulo, São Paulo, SP, Brasil.

Cappi, R. (2017a) A Maioridade Penal nos Debates Parlamentares: motivos do controle e figuras do perigo. Belo Horizonte, MG: Letramento.

Cappi, R. (2017b). A "teorização fundamentada nos dados": um método possível na pesquisa empírica em Direito. In M. R. Machado (org.). Pesquisar Empi- ricamente o Direito (p. 391-422). São Paulo: Rede de Estudos Empíricos em Direito.

Carvalho, S., \& Weigert, M. A. B. (2018). "Making a Drug Dealer": o Impacto dos Depoimentos Policiais e os Efeitos da Súmula no 70 do TJRJ na Construção do Caso Rafael Braga. Rev. de Estudos Criminais, Rio Grande do Sul, 17(68), 45-77.

Costa, A. T. M., \& Junior, A. O. (2016). Novos padrões de investigação policial no Brasil. Rev. Sociedade e Estado, Brasília, 31 (1), 147-164.

Carlos, J. O. (2015) Drug Policy and Incarceration in São Paulo (Brazil). International Drug Policy Consortium Publications, 01.

Couto, V. A., Ribeiro, L. M. L., \& Rocha, R. L. S. (2017). Nas malhas da justiça: uma análise dos dados oficiais de indiciados por drogas em Belo Horizonte (2008-2015). Opin. Publica, Campinas, 23(2), 397-428.

Foucault, M. (2013). A Verdade e as formas jurídicas. (Trad. Eduardo Jardim e Roberto Machado, 4 a ed.). Rio de Janeiro: Nau Editora.

Garcia, C. S. (2005). Os descaminhos da punição A Justiça Penal e o Tráfico de Drogas. Dissertação de Mestrado, Universidade de São Paulo, São Paulo, SP, Brasil. Grillo, C. C., Policarpo, F., \& Verissimo, M. (2011) A "dura" e o "desenrolo": efeitos práticos da nova lei de drogas no Rio de Janeiro. Revista Sociologia Política, 19(40), 135-148.

Glaser, B. G., \& Strauss, A. L. (2011). The Discovery of Grounded Theory: strategies for qualitative research. Estados Unidos da América: AldineTransaction.

Haber, C. D. (Coord.). n/a et al. (2018) Relatório Final Pesquisa Sobre as Sentenças Judiciais por Tráfico De Drogas na Cidade e Região Metropolitana do Rio de Janeiro. Departamento de Pesquisa, Defensoria Pública Geral do Rio de Janeiro. Rio de Janeiro, RJ, Brasil. Herdy, E., \& Matida, J. (2016) As inferências probatórias: compromissos epistêmicos, normativos e interpretativos. In José Eduardo Cunha. (org.). Epistemologias críticas do direito (p. 209-239). Rio de Janeiro: Lumen Juris.

Instituto Igarapé. (2015). Critérios objetivos de distinção entre usuários e traficantes de drogas - cenários para o Brasil. Nota técnica.

Jesus, M. G. M. (2016). 'O que está no mundo não está nos autos': a construção da verdade jurídica nos processos criminais de tráfico de drogas. Tese de Doutorado, Universidade de São Paulo, São Paulo, SP, Brasil. Jesus, M. G. M. (2015). Narrativas policiais: a construção da verdade jurídica nos processos de tráfico de dro- 
gas. In: IV ENADIR - Encontro Nacional de Antropologia do Direito, 2015. São Paulo, SP. Conjunto didático de Filosofia e Ciências Sociais.

Jesus, M. G. M., Oi, A. H., Rocha, T. T., \& Lagatta, P. (2011). Prisão Provisória e Lei de Drogas: um estudo sobre os flagrantes de tráfico de drogas na cidade de São Paulo. São Paulo: Núcleo de Estudos de Violência.

Lemgruber, J. \& Fernandes, M. (2015). Tráfico de drogas na cidade do Rio de Janeiro: Prisão provisória e direito de defesa. Boletim Segurança e Cidadania, n. 17. Lima, R. K. (1989). Cultura jurídica e práticas policiais: a tradição inquisitorial no Brasil. Revista Brasileira de Ciências Sociais, 4(10), 65-84.

Lima, R. K. (1999). Polícia, justiça e sociedade no Brasil: uma abordagem comparativa dos modelos de administração de conflitos no espaço público. Rev. Sociol. Polit., 13.

Mendonça Filho, F. P. (2008). A administração institucional do uso de drogas. In: $32^{a}$ ANPOCS - Associação Nacional de Pós-Graduação e Pesquisa em Ciências Sociais, 2008, Caxambu-MG. Associação Nacional de Pós-Graduação e Pesquisa em Ciências Sociais.

Misse, M. (2010). O inquérito policial no Brasil: Resultados gerais de uma pesquisa. Dilemas - Revista de Estudos de Conflito e Controle Social, 3(7), 35-50.

Prates, F. (2013). La construction du verdict de culpabilité: Magistrature pénale et production de vérité judiciaire au Brésil. Tese de Doutorado. Université de Montreal, UdeM, Canadá.

Pires, A. P., \& Cauchie, J.-F. (2011). Um caso de inovação "acidental" em matéria de penas: a lei brasileira de drogas. Rev. Direito GV, 7(1), 299-330.

Santoucy, L. B., Conceição, M. I. G., \& Sudbrack, M. F. O. (2010). A compreensão dos operadores de direito do distrito federal sobre o usuário de drogas na vigência da nova lei. Psicologia: Reflexão e Crítica, 23(1), 176-185. Vargas, J. D. (2012). Em Busca da "Verdade Real": Tortura e confissão no Brasil ontem e hoje. Sociol. Antropol., 2(3), 237-265.

Data de submissão: 10/11/2019

Data de aceite: 03/12/2019 